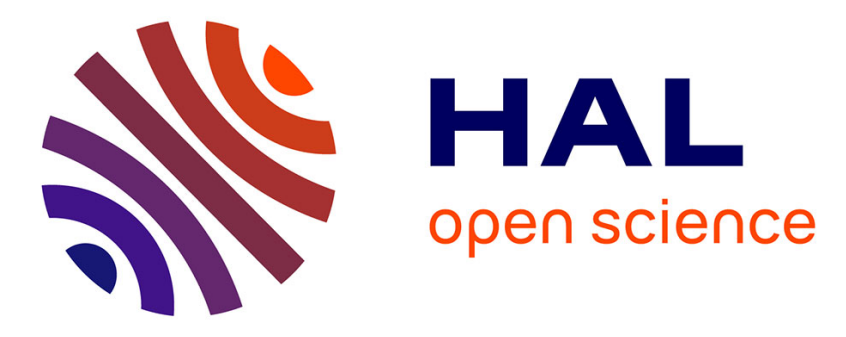

\title{
Trace metals partitioning between particulate and dissolved phases along a tropical mangrove estuary (Can Gio, Vietnam)
}

Nguyen Thành-Nho, Emilie Strady, Tran-thi Nhu-Trang, Frank David, Cyril Marchand

\section{To cite this version:}

Nguyen Thành-Nho, Emilie Strady, Tran-thi Nhu-Trang, Frank David, Cyril Marchand. Trace metals partitioning between particulate and dissolved phases along a tropical mangrove estuary (Can Gio, Vietnam). Chemosphere, 2018, 196, pp.311-322. 10.1016/j.chemosphere.2017.12.189 . hal-02356823

\section{HAL Id: hal-02356823 \\ https://hal.science/hal-02356823}

Submitted on 9 Nov 2019

HAL is a multi-disciplinary open access archive for the deposit and dissemination of scientific research documents, whether they are published or not. The documents may come from teaching and research institutions in France or abroad, or from public or private research centers.
L'archive ouverte pluridisciplinaire HAL, est destinée au dépôt et à la diffusion de documents scientifiques de niveau recherche, publiés ou non, émanant des établissements d'enseignement et de recherche français ou étrangers, des laboratoires publics ou privés. 


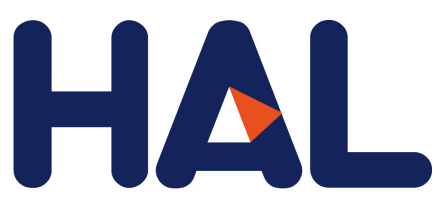

archives-ouvertes

\section{Trace metals partitioning between particulate and dissolved phases along a tropical mangrove estuary (Can Gio, Vietnam)}

Nguyen Thành-Nho, Emilie Strady, Tran-thi Nhu-Trang, Frank David, Cyril Marchand

\section{To cite this version:}

Nguyen Thành-Nho, Emilie Strady, Tran-thi Nhu-Trang, Frank David, Cyril Marchand. Trace metals partitioning between particulate and dissolved phases along a tropical mangrove estuary (Can Gio, Vietnam). Chemosphere, Elsevier, 2018, 196, pp.311-322. 10.1016/j.chemosphere.2017.12.189 . hal02356823

\section{HAL Id: hal-02356823 \\ https://hal.archives-ouvertes.fr/hal-02356823}

Submitted on 9 Nov 2019

HAL is a multi-disciplinary open access archive for the deposit and dissemination of scientific research documents, whether they are published or not. The documents may come from teaching and research institutions in France or abroad, or from public or private research centers.
L'archive ouverte pluridisciplinaire HAL, est destinée au dépôt et à la diffusion de documents scientifiques de niveau recherche, publiés ou non, émanant des établissements d'enseignement et de recherche français ou étrangers, des laboratoires publics ou privés. 


\title{
Trace metals partitioning between particulate and dissolved phases along a tropical mangrove estuary (Can Gio, Vietnam)
}

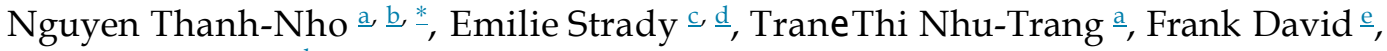 \\ Cyril Marchand $\underline{a}, \underline{b}$ \\ a Department of Analytical Chemistry, Faculty of Chemistry, University of Science, Vietnam National University, Ho Chi Minh City, Viet Nam \\ b IMPMC, Institut de Recherche pour le D' eveloppement (IRD), UPMC, CNRS, MNHN, Noumea, New Caledonia, France \\ ' Univ. Grenoble Alpes, CNRS, IRD, Grenoble INP, IGE, F-38000, Grenoble, France \\ d CARE-HCMUT, Ho Chi Minh City, Viet Nam \\ e Sorbonne Universit' es, MNHN, UPMC Univ Paris 06, UNICAEN, UA, CNRS, IRD, Biologie des Organismes et Ecosyst emes Aquatiques (BOREA), 61 rue Buffon, \\ CP53, 75005, Paris, France
}

h ig h l ig h t s

- Partitioning and distribution of 8 trace metals were studied in a mangrove estuary.

- TSS was the main trace metals carrier during their transit in the estuary.

- The monsoon induced increased metal inputs to the estuary.

- Most of dissolved metals exhibited a non-conservative behavior whatever the season.

- Mn, Crand As were highly reactive, OM or DO playing a key role in their dynamics.

\section{a $r$ t ic le in fo}

\section{Article history:}

Received 20 October 2017

Received in revised form

26 December 2017

Accepted 29 December 2017

Available online 30 December 2017

Handling Editor: Martine Leermakers

\section{Keywords:}

Biogeochemical processes

Salinity gradient

Monsoon effect

Non-conservative behavior

Vietnam

\section{$\mathrm{a} b \mathrm{~s} \mathrm{t} r \mathrm{a} c \mathrm{t}$}

Mangroves can be considered as biogeochemical reactors along (sub)tropical coastlines, acting both as sinks or sources for trace metals depending on environmental factors. In this study, we characterized the role of a mangrove estuary, developing downstream a densely populated megacity (Ho Chi Minh City, Vietnam), on the fate and partitioning of trace metals. Surface water and suspended particulate matter were collected at four sites along the estuarine salinity gradient during $24 \mathrm{~h}$ cycling in dry and rainy seasons. Salinity, $\mathrm{pH}, \mathrm{DO}, \mathrm{TSS}, \mathrm{POC}, \mathrm{DOC}$, dissolved and particulate $\mathrm{Fe}, \mathrm{Mn}, \mathrm{Cr}, \mathrm{As}, \mathrm{Cu}, \mathrm{Ni}, \mathrm{Co}$ and $\mathrm{Pb}$ were measured. TSS was the main trace metals carrier during their transit in the estuary. However, TSS variations did not explain the whole variability of metals distribution. $\mathrm{Mn}, \mathrm{Cr}$ and As were highly reactive metals while the other metals $\left(\mathrm{Fe}, \mathrm{Ni}, \mathrm{Cu}, \mathrm{Co}\right.$ and $\mathrm{Pb}$ ) presented stable log $\mathrm{K}_{\mathrm{D}}$ values along the estuary. Organic matter dynamic appeared to play a key role in metals fractioning. Its decomposition during water transit in the estuary induced metal desorption, especially for $\mathrm{Cr}$ and As. Conversely, dissolved Mn concentrations decreased along the estuary, which was suggested to result from Mn oxidative precipitation onto solid phase due to oxidation and $\mathrm{pH}$ changes. Extra sources as pore-water release, runoff from adjacent soils, or aquaculture effluents were suggested to be involved in trace metal dynamic in this estuary. In addition, the monsoon increased metal loads, notably dissolved and particulate $\mathrm{Fe}, \mathrm{Cr}, \mathrm{Ni}$ and $\mathrm{Pb}$

\footnotetext{
* Corresponding author. Department of Analytical Chemistry, Faculty of Chemistry, University of Science, Vietnam National University, Ho Chi Minh City, Viet Nam.

E-mail address: ntnho@hcmus.edu.vn(N. Thanh-Nho).
}

1. Introduction

Estuaries are key environment for the transfer of trace metals from land to open ocean (Fu et al., 2013; Wang et al., 2016). They are characterized by strong physico-chemical gradients, e.g. salinity, dissolved oxygen (DO), $\mathrm{pH}$, redox condition (Elliott and McLusky, 2002), as well as gradients of organic matter quantity and quality 
(Abril et al., 2002), which may affect trace metal speciation and distribution. Some elements may have a conservative behavior along the estuary, and their distribution is controlled by physical mixing of river and sea waters (de Souza Machado et al., 2016). Conversely, others may have a non-conservative additive or subtractive behavior, which means that due to biogeochemical processes a gain or a loss of dissolved metal concentrations in comparison to the theoretical dilution line will be observed. Metals also have affinities with suspended solid (Lacerda et al., 1988), which are by far the most important metal carriers from the rivers to the coastal area (Yao et al., 2016). Consequently, the distribution and partitioning of trace metals between the particulate and the dissolved phases may vary along the estuarine salinity gradient due mainly to changes in water chemistry ( $\mathrm{pH}, \mathrm{DO}$, organic matter) and ionic strength (Benoit et al., 1994; de Souza Machado et al., 2016)

which can induce trace metal desorption by metal complexation with chloride and sulfate forming soluble inorganic complexes (Acosta et al., 2011; Greger et al., 1995) or metal adsorption by cation exchange capacity (Wang et al., 2016; Yang and Wang, 2017).

In developing countries, the capacity of wastewater treatment plants are not sufficient enough to treat the metal loads from urban, domestic or industrial activities, which are thus released into the

rivers and then estuaries. As most of the tropical estuaries are colonized by mangrove forests (Giri et al., 2011), those inorganic contaminants can thus be deposited in these ecosystems.

Mangrove sediments are known to act as a sink of trace metals due

to their richness in organic matter, their clay content, and their dense root systems that can efficiently trap suspended matter and their associated metals from the water column (Chu et al., 1998;

Harbison, 1986; Marchand et al., 2006; Natesan et al., 2014).

However, because of the reactivity of these sediments and the

alternation between oxic and anoxic conditions, trace metals bearing phases may be dissolved (Marchand et al., 2016; Noe $€$ let al., 2014) and metals can, thus, be exported to adjacent tidal creeks (Holloway et al., 2016). As mangroves have specific ecological, sociological and economical roles, notably for the local population and the fishing resources (Lee et al., 2014), their ecological status and the understanding of the metal fate in their water column is highly relevant.

Can Gio is the biggest mangrove forest in Vietnam, being a wellknown sea-food producing area, and having its core zone registered as a UNESCO biosphere reserve. Can Gio is also an estuary located at the confluence of Sai Gon and Dong Nai Rivers, which drain a megacity of almost 10 million inhabitants, Ho Chi Minh City. In addition, this estuary is acting as a unique gate for water traffic connecting Ho Chi Minh City to the South China Sea. Despite the long list of ecosystem services provided by the Can Gio mangrove and the increasing anthropogenic pressure on this zone (Kuenzer and Tuan, 2013), there is a lack of published studies along this estuary, especially on trace metal dynamics. Some publications were interested in organic compounds (Minh et al., 2007; Oxmann et al., 2010), and recently accumulation of trace metal in sediments fringing the mangrove was studied (Costa-Boddeker et al., 2017). The only available data concerning trace metals distribution was reported in surface water of the Sai Gon River, upstream the mangrove (Strady et al., 2017a).

Within this context, our main objectives were to determine: i) the spatio-temporal variations of salinity, $\mathrm{pH}, \mathrm{DO}$, total suspended solids (TSS), particulate organic carbon (POC) and dissolved organic carbon (DOC) along this mangrove estuary, from the downstream end of Ho Chi Minh City to the South China Sea; ii) the distribution and partitioning of metals between the particulate and dissolved phases along the salinity gradient; iii) the potential influence of the monsoon on the fate of trace metals. Our main hypothesis are: i) a decrease of trace metals concentrations due to the dilution with marine waters and/or desorption from bearing phase resulting from increased oxygen content; ii) increased inputs during the monsoon caused by elevated runoff and soil leaching. To reach our goals, water and suspended matter samples were collected for organic carbon and trace metals analysis during $24 \mathrm{~h}$ cycling in order to take into account the whole tidal cycling at four sites along the estuary during two distinct seasons.

\section{Materials and methods}

\subsection{Study area}

The Can Gio mangrove is located in the south of Vietnam $\left(10^{\circ} 22^{0} 14^{00}-10^{\circ} 40^{0} 09^{00} \mathrm{~N} ; 106^{\circ} 46^{0} 12^{00}-107^{\circ} 00^{0} 59^{00} \mathrm{E}\right)$ and is part of the densely populated megacity of Ho Chi Minh City (HCMC almost 10 million of inhabitants), $35 \mathrm{~km}$ downstream of the City urban center and industrial zones (Strady et al., 2017a; Vo, 2007). This mangrove covers an area of 35,000 ha (Fig. 1) and is a UNESCO biosphere reserve which can be divided into three areas according to their anthropogenic pressure and level of conservation (Nam et al., 2014): (i) a core zone protected for long term conservation of biodiversity, in which human activities are prohibited, (ii) a buffer zone to protect the core zone with limited human activities and (iii) a transition zone with humans activities like agriculture, aquaculture, fishing, salt-pan, trading and tourism. Can Gio mangrove is home to high biodiversity with more than 200 species of fauna (e.g. planktonic and benthic organism, fishes, reptiles and amphibians) and 20 species of flora, in which three mangrove species are dominant Avicenia alba, Rhizophora apiculata, Phoenix paludosa (Kuenzer and Tuan, 2013). Freshwater inputs originate from the Sai Gon and Dong Nai Rivers, emptying out the South

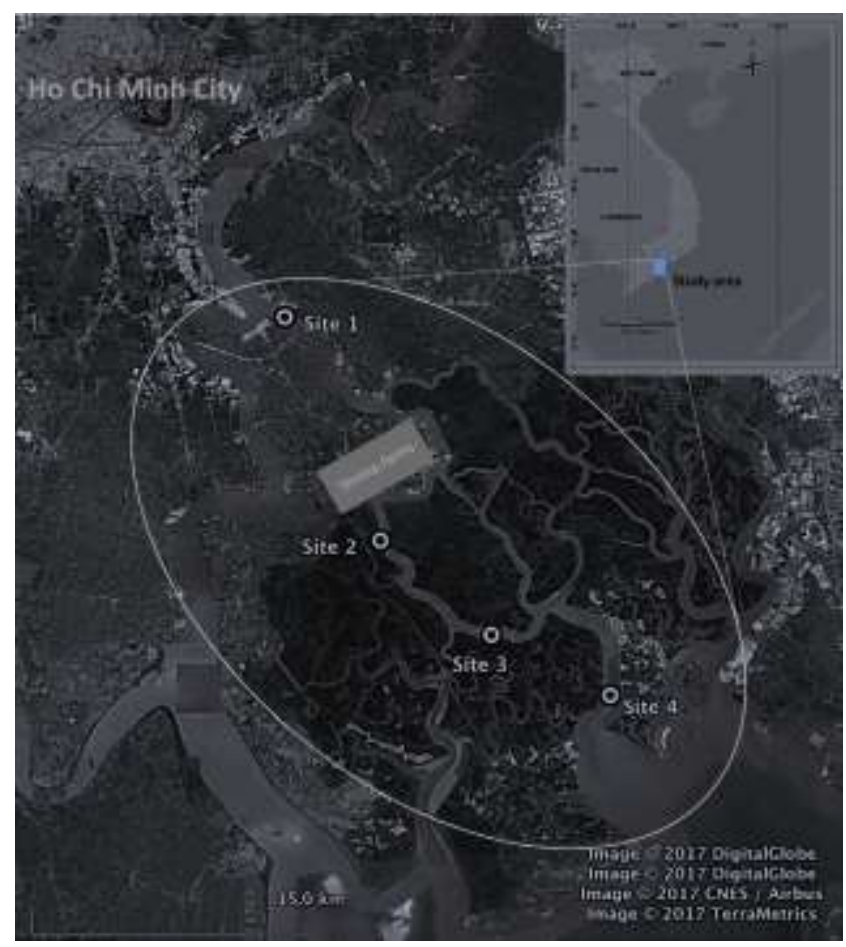

Fig. 1. Satellite image of Can Gio mangrove forest (black area) and sampling location along the estuary. Site 1 characterizing the riverine and urban end-member; Site 2 characterizing aquaculture activities (mainly shrimps) and the buffer zone of mangrove forest; Site 3 characterizing the core of mangrove forest; site 4 characterizing the marine end-member. 
China Sea via the Long Tau and Soai Rap Rivers. The hydrology is affected by a semi-diurnal tidal regime with a tidal amplitude up to $4 \mathrm{~m}$, and by typical tropical monsoon climate, with a rainy season lasting from May to October and a dry season extending from November to April. The annual average temperature and precipitation are $25.8{ }^{\circ} \mathrm{C}$ and $1400 \mathrm{~mm}$, respectively. During the rainy season, highest precipitation can reach up $400 \mathrm{~mm}$ in September while it is usually less than $80 \mathrm{~mm}$ per month during the dry season. The main economic activities of local people are: aquaculture, in which shrimp farming dominate with approximately 3160 ha, fisheries, agriculture and salt production (Tuan and Kuenzer, 2012). The industrial activities are excluded of the three zones (core, buffer and transition zones) of the Can Gio mangroves but are developed to $35 \mathrm{~km}$ upstream the mangrove close to HCMCity urban center and along the Dong Nai river (mainly plastic and rubber production, mechanical engineering, electrical engineering, packaging, textile and dyes industry, oil activities and cement production).

\subsection{Field sampling and measurements}

Samples were collected during $24 \mathrm{~h}$ tidal cycles, with a sampling every $2 \mathrm{~h}$, at four sites along the Long Tau River according to their environmental characteristics and their locations into the different zones of the mangrove described in the section above: site 1 $\left(10^{\circ} 39^{0} 55^{00} \mathrm{Ne} 106^{\circ} 47^{0} 30^{00} \mathrm{E}\right)$ characterizing the riverine and urban end-member; site $2\left(10^{\circ} 34^{0} 19^{00} \mathrm{Ne} 106^{\circ} 50^{0} 11^{00} \mathrm{E}\right)$ located in the buffer zone of the mangrove forest characterizing aquaculture activities (mainly shrimps); site $3\left(10^{\circ} 31^{0} 04^{00} \mathrm{Ne} 106^{\circ} 53^{0} 13^{00} \mathrm{E}\right)$ located in the core zone of the mangrove forest; site $4\left(10^{\circ} 29^{0} 32^{00} \mathrm{Ne} 106^{\circ} 56^{0} 55^{00} \mathrm{E}\right)$ characterizing the marine end-member (Fig. 1). The sampling campaigns were carried out during dry season (January and February 2015) and rainy season (September and October 2015).

The physicoechemical parameters such as salinity, $\mathrm{pH}$ and temperature $\left({ }^{\circ} \mathrm{C}\right)$ were logged continuously in-situ using a multiprobe (Yellow Spring Instrument ${ }^{\circledR}$ meters YSI 6920). DO was monitored with a HOBO Dissolved Oxygen data logger (HOBO U26001). $\mathrm{pH}$ probes were pre-calibrated using buffer solutions: 4, 7 and 10 (NIST scale) at the same day prior of sampling. Probes were immerged $50 \mathrm{~cm}$ below the air-water interface and data were recorded every at $5 \mathrm{~min}$.
At each sampling site and time, surface waters $(50 \mathrm{~cm}$ below the air-water interface) were collected in duplicates using a bucket, immediately transferred into acid pre-cleaned polypropylene bottles $(1 \mathrm{~L})$ - previously rinsed with surface water. Then, a first aliquot of surface water was filtered through $0.2 \mathrm{~mm}$ PTFE Omnipore ${ }^{\mathrm{TM}}$ Membrane Filters for trace metal analysis. The filtrate was transferred into pre-cleaned $50 \mathrm{~mL}$ polypropylene, immediately acidified to $\mathrm{pH}<2$ using concentrated suprapur ${ }^{\circledR}$ $\mathrm{HNO}_{3}\left(\mathrm{HNO}_{3} /\right.$ sample $\left.1 / 41 / 1000(v / v)\right)$ for dissolved trace metals $\mathrm{M}_{\mathrm{D}}$, while the filters were kept in pre-cleaned plastic petri dishes for suspended particulate trace metals analysis $\left(\mathrm{M}_{\mathrm{P}}\right)$. Both samples were maintained in cool box during sampling campaign and stored at $4{ }^{\circ} \mathrm{C}$ in the laboratory for dissolved metal and at $-18{ }^{\circ} \mathrm{C}$ for particulate metal (Strady et al., 2017b). Filters were then freeze dried, weighed and preserved at room temperature until analysis. A second aliquot of surface water was filtered in triplicates through pre-combusted $\left(500^{\circ} \mathrm{C}\right)$ and pre-weighted glass fiber filters (Whatman ${ }^{\circledR} \mathrm{GF} / \mathrm{F} 0.7 \mathrm{~mm}$ ): the filter was stored at $-18^{\circ} \mathrm{C}$ for particulate organic carbon (POC) and total suspended solid (TSS) determinations while the filtrate was transferred into sterile 15 $\mathrm{mL}$ polypropylene, acidified using concentrated suprapur ${ }^{\circledR} \mathrm{HCl}$ and stored at $4{ }^{\circ} \mathrm{C}$ in fridge for dissolved organic carbon (DOC) analysis.

\subsection{Samples analysis}

\subsubsection{Dissolved metals concentrations $\left(M_{D}\right)$}

Dissolved $\mathrm{Mn}, \mathrm{Fe}, \mathrm{Cr}, \mathrm{Co}, \mathrm{Ni}, \mathrm{Cu}$, As and $\mathrm{Pb}$ concentrations were directly measured by Thermo Scientific iCAPQ ICP-MS using internal standard calibration (AETE-ISO platform, OSU-OREME/Universite' de Montpellier), with a Kinetic Energy Discrimination e Argon Gas Dilution module (KED e AGD mode) (Kutscher et al., 2014). Accuracy and precision were controlled using certificate reference material: riverine water (SLRS6) for salinity lower than 1 and estuarine water (SLEW-3) for salinity higher than 1 (Table 1a).

\subsubsection{Particulate metal concentrations $\left(M_{P}\right)$}

Particulate $\mathrm{Mn}, \mathrm{Fe}, \mathrm{Cr}, \mathrm{Co}, \mathrm{Ni}, \mathrm{Cu}$, As and $\mathrm{Pb}$ concentrations were analyzed according to a total extractable metal digestion adapted from the USEPA 3051a method (USEPA, 2007). Filters were put on PTFE vessel in which $6 \mathrm{~mL}$ of concentrated $\mathrm{HNO}_{3}$ and $2 \mathrm{~mL}$ of

Table 1

Quality control of analytical methods applied for dissolved and particulate metal concentrations analysis: a) accuracy, precision and detection limit using estuarine water SLEW-3; b) BCR-277R for wet digestion method.

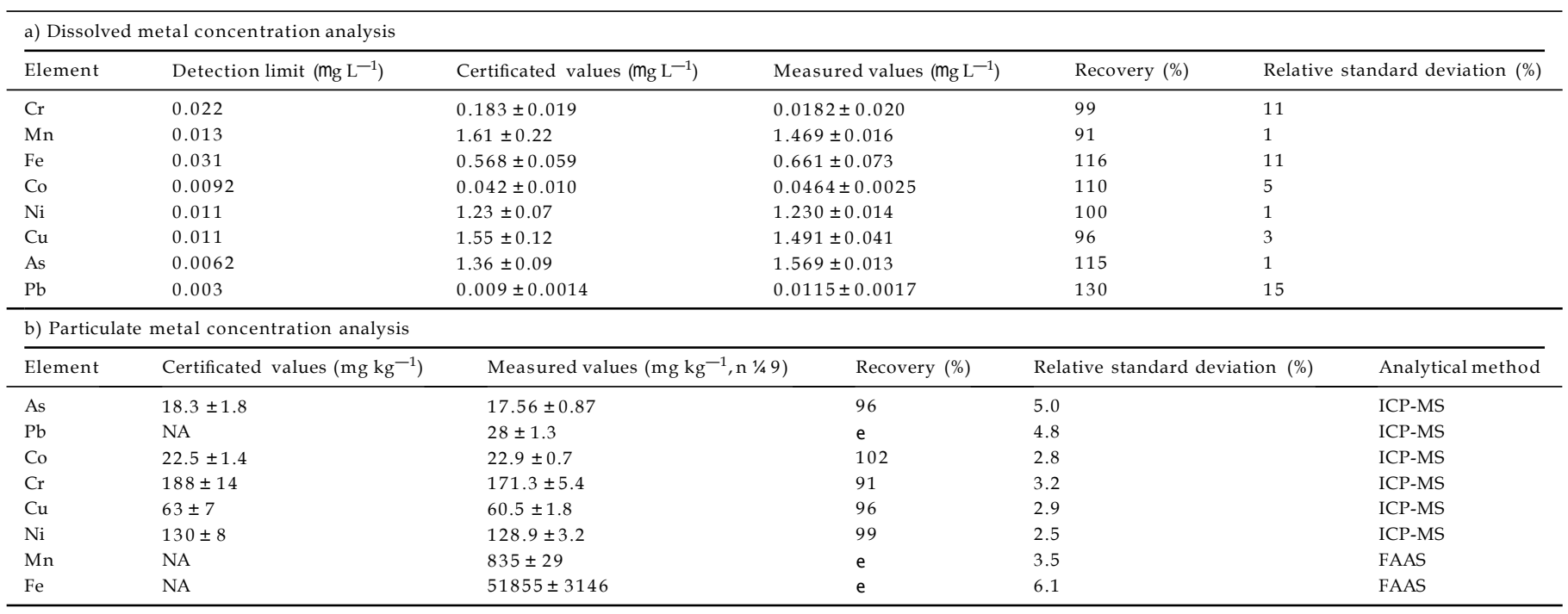


concentrated $\mathrm{HCl}$ were added. The vessels were placed into ultrasonic bath during $15 \mathrm{~min}$ and were then heated at $110{ }^{\circ} \mathrm{C}$ during $12 \mathrm{~h}$ in the electrical oven. After cooling, the digestions were put again in ultrasonic bath during $15 \mathrm{~min}$, and temperature was then increased up to $160{ }^{\circ} \mathrm{C}$ during $4 \mathrm{~h}$. The samples were cooled and filtrated to reject residue, then diluted to $25 \mathrm{~mL}$ with deionized water and stored in pre-cleaned PP tubes at $4{ }^{\circ} \mathrm{C}$ until analysis. All reagents were of analysis grade (Merck) and were purified using a sub-boiling quartz distillation equipment prior digestion.

Concentrations of $\mathrm{Cr}, \mathrm{Co}, \mathrm{Ni}, \mathrm{Cu}$, As and $\mathrm{Pb}$ were measured by ICP eMS (Agilent 7700x) using spiked ${ }^{103} \mathrm{Rh}$ and ${ }^{197} \mathrm{Au}$ as internal standard while $\mathrm{Fe}$ and $\mathrm{Mn}$ concentrations were determined by Flame Atomic Absorption Spectrophotometer (Shimadzu AA6650). The analytical precision and accuracy were insured by analyzing certificate reference material estuarine sediments (BCR277R) (Table 1b).

\subsubsection{Dissolved organic carbon (DOC) and particulate organic carbon (POC) analysis}

The DOCanalysis were performed on a Shimadzu ${ }^{\circledR}$ TOC-L series analyzer employing a $680{ }^{\circ} \mathrm{C}$ combustion catalytic oxidation method. The analyzer was combined with a solid sample module (SSM-5000A) heated up to $900{ }^{\circ} \mathrm{C}$ for POC measurement (Leopold et al., 2013). For both, $40 \%$ glucose standard was used for calibrations. Repeated measurements of the standard at different concentrations indicated a measurement deviation $<2 \%$.

\subsection{Data analysis}

In order to better understand the interaction of trace metals between dissolved and particulate phases along the salinity gradient, the partitioning coefficient $\left(\mathrm{K}_{\mathrm{D}}\right)$ was calculated. The $\mathrm{K}_{\mathrm{D}}$ provide a quantitative value for the partitioning of metal concentration between solution and particle. It is defined as the ratio of particulate metal concentration $\left(\mathrm{M}_{\mathrm{P}}\right)$ to dissolved metal concentration $\left(\mathrm{MD}_{\mathrm{D}}\right)$ in the water column (Turner et al., 1993).

\section{$\mathrm{K}_{\mathrm{D}}{ }^{1 / 4} \mathrm{MP} / \mathrm{M}_{\mathrm{D}}$}

where $M_{p}$ is the particulate metal concentration; $M_{D}$ is the dissolved metal concentration.

The Pearson correlation coefficient and the one-way ANOVA were performed using statistical package software (SPSS; version 23) to identify major relationships between metal concentrations and physico-chemical parameters as well as interrelations between metals together in order to identify the main factors controlling metal partitioning.

\section{Results and discussion}

\subsection{Spatial and seasonal variations of physico-chemical parameters}

Can Gio is a tropical mangrove-dominated estuary characterized by semi-diurnal tidal regime and subject to a monsoon season. All the studied parameters varied from the upstream site, at the edge of Ho Chi Minh City, to the downstream site, at the mouth of the estuary (Table 2, Fig. 2). In addition, some seasonal variations were observed. Salinity, DO and DOC were affected by seasonal change (ANOVA, $\mathrm{p}<.01$ ), whereas $\mathrm{pH}$, TSS and POC were not (ANOVA, $\mathrm{p}>$ $.05)$. From the upstream site to the sea, salinity varied from 0 to 25 during the rainy season and from 5 to 25 during the dry season. The very low salinity $(<2)$ observed at the upstream site during the rainy season, whatever the tides, was attributed to intense rainfall increasing the freshwater inflow and limiting the saline intrusion. The $\mathrm{pH}$ values varied from 6.8 to 7.8 during the dry season and from
6.4 to 7.5 during the rainy season, and were positively correlated to salinity ( $\mathrm{r} 1 / 40.96$ and 0.97 during the dry and the rainy season, respectively). $\mathrm{DO}$ ranged from 3.5 to $7.0 \mathrm{mgO}_{2} \mathrm{~L}^{-1}$ and from 1.2 to $5.3 \mathrm{mgO}_{2} \mathrm{~L}^{-1}$ during the dry and the rainy seasons respectively, also increasing with salinity $\left(\mathrm{r}^{1 / 4} 0.86\right.$ and 0.94 for the dry and the rainy season, respectively). Both $\mathrm{pH}$ and $\mathrm{DO}$ reflected the mixing of fresh and sea waters (Fig. 2). The acidic $\mathrm{pH}$ values measured at the upstream site during the monsoon are likely related to the contribution of the Sai Gon River, which is characterized by low $\mathrm{pH}$, down to 5.7 (Strady et al., 2017a), possibly due to the leaching of the surrounding acidic sulfate soils (Nguyen et al., 2011), but also to the decay processes of organic inputs. The latter may also be responsible for the drastic decrease of DO values measured at this site, down to $1.2 \mathrm{mgO}_{2} \mathrm{~L}^{-1}$. These organic inputs may originate from domestic and urban discharges of Ho Chi Minh City urban center and also from the industrial areas located along the Sai Gon and Dong Nai Rivers.

The POC concentrations decreased along the salinity gradient but not linearly, from $3.8 \%$ to $1.3 \%$, and from $5.0 \%$ to $1.7 \%$ during dry and rainy seasons, respectively. Those patterns suggest that POC distributions resulted both from the dilution by seawater and from the decomposition processes occurring during its transit in the estuary (Fig. 2). Decreasing POC concentrations have also been observed in most estuaries like in temperate European estuaries (Abril et al., 2002; Etcheber et al., 2007) or tropical estuaries like in the Mandovi Estuary (Shynu et al., 2015). At the upstream site, DOC concentrations ranged from $1.22 \mathrm{mgC} \mathrm{L}^{-1}$ to $5.89 \mathrm{mgC} \mathrm{L}^{-1}$ during the rainy season and could be related to intense inputs from the city and industrial zones (Strady et al., 2017a). Along the salinity gradient, DOC concentrations varied from $1.64 \mathrm{mgC} \mathrm{L}^{-1}$ to $3.54 \mathrm{mgC} \mathrm{L}^{-1}$ and were stable during the rainy season. However, during the dry season, DOC values slightly increased in the downstream part of the estuary, which might be the result of intense carbon degradation processes in well oxygenated waters (Ni et al., 2008), and possible inputs from the adjacent mangrove forest (Dittmar and Lara, 2001).

The TSS concentrations varied from 16 to $361 \mathrm{mg} \mathrm{L}^{-1}$ and $23 \mathrm{e}^{283} \mathrm{mg} \mathrm{L}^{-1}$ during the dry and the rainy season, respectively, and did not present any conclusive distribution along the salinity gradient (Fig. 2). They were in the same range than those measured upstream the mangrove by Strady et al. (2017a), whatever the seasons. However, higher values were measured at site 2 , located within the outlet of small tributaries, which are suggested to be related to disturbance of bottom sediment due to confluences of watersheds (Cang et al., 2007) and the increased erosion of the river banks caused by the sinuous flow (Nam et al., 2014).

To summarize, the spatial and seasonal variations of the physico-chemical properties reflected well the mixing of the fresh and the sea waters in the estuary. The characteristics of the upstream site during the monsoon are those of the Saigon River: salinity almost null, acidic $\mathrm{pH}$ values, low DO concentrations, and high POC and DOC contents. We suggest that this site can be considered as the river end-member during this season. During the dry season, the characteristics of site 1 were estuarine ones, with a mix between fresh and sea waters, and thus cannot allow us to determine inputs in the estuary at this season. Concerning the downstream site, it exhibited similar salinity, $\mathrm{pH}$ and $\mathrm{DO}$ ranges during both seasons and was thus considered as the seawater end member of the studied system.

\subsection{Trace metal distributions at the upstream site during the monsoon}

The characteristics of the upstream site during the monsoon being those of the river end-member, and not those of estuarine 


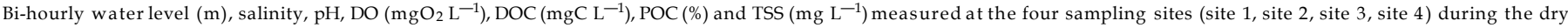
and the wet seasons.

Site Label Dry season

Wet season

Water level $\mathrm{m}$ Sal $\quad \mathrm{pH} \quad \mathrm{DO} \mathrm{mgO}_{2} \mathrm{~L}^{-1}$ DOC $\mathrm{mgC} \mathrm{L}^{-1}$ POC $\%$ TSS mg L $\mathrm{L}^{-1}$ Water level m Sal $\quad \mathrm{pH} \mathrm{DO} \mathrm{mgO}_{2} \mathrm{~L}^{-1} \mathrm{DOC}_{\mathrm{mgC}} \mathrm{L}^{-1} \mathrm{POC}_{\mathrm{TSS}} \mathrm{mg} \mathrm{L}^{-1}$

\begin{tabular}{|c|c|c|c|c|c|c|c|c|c|c|c|}
\hline S1 & h0 & 12.8 & 8.846 .873 .89 & 2.8 & 3.76 & 16.6 & 11 & $0.556 .57 \quad 1.84$ & 2.36 & 5.05 & 44.53 \\
\hline S1 & h2 & 13.6 & 6.813 .47 & 3.25 & 3.84 & 17.23 & 10.6 & 6.551 .21 & 3.88 & 5.04 & 45.66 \\
\hline S1 & h4 & 14.6 & $7.926 .93 \quad 4.07$ & 3.18 & 3.4 & 18.96 & 10.8 & 6.551 .32 & 5.89 & 4.35 & 58.46 \\
\hline S1 & h6 & 16.2 & 10.687 .094 .62 & 2.94 & 2.6 & 29.03 & 11.3 & 0.646 .591 .8 & NA & 3.94 & 62.23 \\
\hline S1 & h 8 & 15.1 & $12.567 .17 \quad 4.15$ & 2.92 & 2.95 & 21.53 & 11.9 & $1.926 .68 \quad 2.33$ & 3.42 & 2.92 & 136.76 \\
\hline S1 & h 10 & 14.2 & 11.017 .14 .1 & 3.33 & 2.41 & 33.46 & 12.2 & $3.196 .75 \quad 2.57$ & 2.52 & 4.96 & 22.8 \\
\hline S1 & h12 & 13.1 & 10.057 .093 .52 & 2.92 & 2.73 & 25.1 & 12 & 0.916 .621 .72 & 2.04 & 4.73 & 34.00 \\
\hline S1 & h14 & 12.9 & 9.777 .043 .6 & 3.59 & 2.39 & 60.26 & 11.8 & 0.756 .61 .59 & 3.18 & 4.00 & 42.53 \\
\hline S1 & h16 & 12.4 & $8.156 .97 \quad 4.17$ & 3.35 & 2.7 & 43.06 & 11.9 & 0.696 .61 .64 & 2.42 & 4.04 & 42.96 \\
\hline S1 & h18 & 13.6 & $\begin{array}{lll}8.44 & 7 & 4.65\end{array}$ & 2.54 & 2.98 & 22.96 & 12.1 & $0.846 .61 \quad 1.77$ & 1.22 & 4.36 & 32.9 \\
\hline S1 & h20 & 15.3 & 10.196 .994 .04 & 3.12 & 3.12 & 27.53 & 11.8 & $0.836 .64 \quad 2.26$ & 2.44 & 4.45 & 37.7 \\
\hline S1 & h22 & 15.3 & $11.436 .84 \quad 4.65$ & 3.88 & 2.52 & 42.56 & 11.5 & 0.856 .662 .3 & 1.97 & 4.74 & 33.36 \\
\hline S1 & h 24 & 13.5 & 9.176 .874 .08 & 3.83 & 3.61 & 15.96 & 11 & $0.576 .63 \quad 2.12$ & 1.41 & 4.26 & 47.23 \\
\hline S2 & h0 & 11.7 & $21.337 .32 \quad 4.98$ & 4.41 & 1.98 & 198.26 & 10.8 & 17.767 .594 .6 & 2.35 & 2.78 & 53.00 \\
\hline S2 & h2 & 10.8 & $21.717 .43 \quad 4.93$ & 2.47 & 1.94 & 139.43 & 10.6 & $16.77 .37 \quad 4.28$ & 1.96 & 2.31 & 75.96 \\
\hline S2 & h4 & 9.3 & 21.327 .44 .89 & 4.32 & 1.62 & 168.66 & 8 & $15.067 .42 \quad 4.27$ & 1.94 & 1.93 & 236.26 \\
\hline S2 & h6 & 9.4 & 20.227 .394 .96 & 2.3 & 2.02 & 151.16 & 7.3 & $11.787 .24 \quad 3.88$ & 1.99 & 1.99 & 178.33 \\
\hline S2 & h 8 & 10.5 & $20.177 .38 \quad 4.87$ & 2.62 & 1.28 & 70 & 8.2 & 6.497 .013 .16 & 2.12 & 2.64 & 50.76 \\
\hline S2 & h10 & 11.1 & $21.567 .42 \quad 4.84$ & 2.39 & 1.31 & 61.53 & 10.8 & $8.78 \quad 7.28 \quad 3.93$ & 2.3 & 2.01 & 178.63 \\
\hline S2 & h12 & 11.1 & $22.677 .45 \quad 4.8$ & 4.11 & NA & 147.9 & 13.3 & 16.287 .464 .07 & 1.64 & 1.67 & 266.8 \\
\hline S2 & h14 & 9.7 & 21.697 .364 .87 & 4.02 & NA & 108.96 & 13.6 & 17.077 .494 .12 & 1.86 & 2.03 & 82.56 \\
\hline S2 & h16 & 8.2 & $20.97 .38 \quad 4.85$ & 4.72 & NA & 206.6 & 8.6 & 15.977 .394 .05 & 1.89 & 2.29 & 190.7 \\
\hline S2 & h18 & 7.5 & $18.87 .33 \quad 4.85$ & 3.62 & NA & 361.16 & 7.6 & $14.887 .38 \quad 3.94$ & 2.82 & 2.11 & 283.06 \\
\hline S2 & h 20 & 8.1 & 13.897 .194 .52 & 2.8 & NA & 93.96 & 7.3 & 10.317 .173 .51 & 3.54 & 2.22 & 80.23 \\
\hline S2 & h22 & 10.3 & 17.557 .34 .75 & 3.19 & NA & 55.13 & 9.8 & 10.927 .263 .98 & 2.38 & 2.62 & 67.36 \\
\hline S2 & h 24 & 10.8 & $21.177 .38 \quad 4.83$ & 3.13 & NA & 281.33 & 10.5 & $15.827 .43 \quad 3.93$ & 2.03 & 2.25 & 170.23 \\
\hline S3 & h0 & NA & NA NA NA & NA & NA & NA & 11.8 & 15.867 .433 .58 & 2.09 & 2.65 & 30.76 \\
\hline S3 & h2 & 12.6 & NA $\quad$ NA 4.93 & 3.77 & 1.66 & 77.8 & 11.2 & $14.717 .35 \quad 3.25$ & 2.07 & 2.47 & 51.16 \\
\hline S3 & h4 & 12.7 & NA NA 5.13 & 2.22 & 1.7 & 167 & 11.4 & 13.477 .293 .11 & 2.01 & 2.51 & 48.26 \\
\hline S3 & h6 & 12.8 & NA NA 5.36 & 2.3 & 1.49 & 73.8 & 12.3 & 13.477 .313 .34 & 2.24 & 2.92 & 33.3 \\
\hline S3 & h 8 & 11.7 & NA NA 5.55 & 2.54 & 1.51 & 44.66 & 12.9 & 17.057 .453 .61 & 1.78 & 2.46 & 38.8 \\
\hline S3 & h 10 & NA & NA NA NA & NA & NA & NA & 13.3 & 18.937 .563 .8 & 2.41 & 2.92 & 43.83 \\
\hline S3 & h12 & 10.3 & NA $\quad$ NA 4.99 & 2.77 & 1.57 & 107.46 & 13.1 & 20.187 .664 .73 & 2.04 & 2.9 & 36.53 \\
\hline S3 & h14 & 10.6 & NA $\quad$ NA 4.91 & 2.36 & 1.77 & 52.46 & 12.9 & $16.487 .48 \quad 4.17$ & 1.82 & 3.51 & 31.5 \\
\hline S3 & h16 & 12.4 & NA $\quad$ NA 4.98 & 3.94 & 1.29 & 53.9 & 12.7 & $16.687 .47 \quad 3.79$ & 2.39 & 2.65 & 33.23 \\
\hline S3 & h18 & 12.7 & NA $\quad$ NA 5.11 & 2.82 & 1.53 & 54.96 & 12.6 & $16.987 .48 \quad 3.58$ & 2 & 2.86 & 36.86 \\
\hline S3 & h 20 & 11.3 & NA NA 5.17 & 3.1 & 1.48 & 39.7 & 13.1 & $16.97 .48 \quad 3.72$ & 2.08 & 2.92 & 24.56 \\
\hline S3 & h 24 & 10.6 & NA $\quad$ NA 5.22 & 2.79 & 1.5 & 66.8 & 12.9 & 17.217 .53 .88 & 2.14 & 2.78 & 24.5 \\
\hline S4 & ho & 12.6 & 26.067 .756 .82 & 3.66 & 1.66 & 73.56 & 12.6 & 16.527 .54 .2 & 2.21 & 3.06 & 23.23 \\
\hline S4 & h2 & 12.3 & 26.17 .817 .01 & 4.48 & 1.58 & 45.43 & 12.3 & 18.937 .393 .86 & 2.2 & 2.22 & 41.96 \\
\hline S4 & h4 & 12.1 & 25.917 .816 .85 & 3.64 & 1.26 & 42.3 & 13.5 & $23.017 .59 \quad 4.52$ & 1.66 & 1.85 & 62.36 \\
\hline S4 & h 6 & 12 & 24.177 .736 .49 & 3.64 & 1.58 & 40.66 & 14 & 25.617 .75 .27 & 3.19 & 1.87 & 50.06 \\
\hline S4 & h 8 & 12.6 & $25.247 .76 \quad 6.65$ & 4.32 & 2.09 & 34.83 & 12.3 & 22.927 .594 .97 & 2.32 & 1.82 & 60.73 \\
\hline S4 & h 10 & 13 & 25.787 .796 .75 & 4.16 & 2.9 & 34.83 & 12.4 & $21.437 .48 \quad 4.29$ & 2.24 & 1.83 & 89.66 \\
\hline S4 & h12 & 12.5 & 25.567 .776 .61 & 4.84 & 2.37 & 28.66 & 14.1 & $20.097 .44 \quad 4.09$ & 1.89 & 1.84 & 42.8 \\
\hline S4 & h14 & 11.3 & 23.637 .696 .24 & 3.28 & 1.77 & 78.73 & 14.5 & $23.097 .57 \quad 4.51$ & 1.91 & 2.02 & 51.06 \\
\hline S4 & h16 & 11 & 22.787 .645 .97 & 3.92 & 2.33 & 121.86 & 13.8 & $24.097 .63 \quad 4.63$ & 2.71 & 2.18 & 48.43 \\
\hline S4 & h18 & 11.4 & $20.987 .58 \quad 5.84$ & 4.44 & 2.38 & 50.63 & 13.1 & $23.747 .59 \quad 4.83$ & 2.35 & 2.09 & 46.46 \\
\hline S4 & h20 & 11.9 & 23.597 .645 .99 & 4.46 & 1.97 & 93.93 & 11.7 & $21.927 .52 \quad 4.53$ & 3.46 & 2 & 120.93 \\
\hline S4 & h22 & 12.8 & 25.977 .756 .57 & 3.79 & 1.85 & 98.8 & 11.4 & 19.447 .414 .37 & 2.78 & 2.09 & 102.76 \\
\hline S4 & h 24 & 13.1 & $25.827 .76 \quad 6.6$ & 3.8 & 1.89 & 54.33 & 12 & $18.017 .38 \quad 3.95$ & 3.14 & 2.42 & 39.73 \\
\hline
\end{tabular}

waters, we choose to discuss them separately from the other data in order to evidence riverine trace metals inputs in the Can Gio Estuary. The dissolved concentrations measured during this period were $\left(\mathrm{mg} \mathrm{L}^{-1}\right)$ : $\mathrm{Mn}_{\mathrm{D}}, 3.4 \mathrm{e} 37 ; \mathrm{Fe}_{\mathrm{D}}, 2.4 \mathrm{e} 18 ; \mathrm{Cu}_{\mathrm{D}}, 0.2 \mathrm{e} 1.5 ; \mathrm{Pb}_{\mathrm{D}}$, 0.15e2.1; $\mathrm{Ni}_{\mathrm{D}}, 0.3 \mathrm{e} 1.37 ; \mathrm{As}_{\mathrm{D}}, 0.09 \mathrm{e} 1.4 ; \mathrm{Cr}_{\mathrm{D}}, 0.053 \mathrm{e} 0.26$ and $\mathrm{Co}_{\mathrm{D}}$ $0.01 \mathrm{e} 0.5$ (Fig. 4; supplementary data 1) while the particulate concentrations were $\left(\mathrm{mg} \mathrm{kg}^{-1}\right)$ : $\mathrm{Fe}_{\mathrm{p}}, 42,959 \mathrm{e} 55,238 ; \mathrm{Mn}_{\mathrm{p}}$, 306e 822; $\mathrm{Cr}_{\mathrm{p}}, 73 \mathrm{e} 131 ; \mathrm{Ni}_{\mathrm{p}}, 57 \mathrm{e} 93 ; \mathrm{Cu}_{\mathrm{p}}, 43 \mathrm{e} 76 ; \mathrm{Pb}, 18 \mathrm{p} 27$; $\mathrm{Cop}_{\mathrm{p}}$, $10 \mathrm{e} 19$ and $\mathrm{As}_{\mathrm{p}}, 9 \mathrm{e} 14$ ( $\mathrm{Fig} .4$; supplementary data 1). Both dissolved and particulate concentrations were in the same range as previously measured in the Sai Gon River (Nguyen et al., 2011; Strady et al., 2017a) and were in the low range of World River average concentrations (Gaillardet et al., 2014; Viers et al., 2009). We noticed that the higher dissolved and particulate concentrations were measured during the ebb tide, namely during riverine water flowing, attesting their inputs from urban and anthropogenic sources (Strady et al., 2017a). Elevated $\mathrm{Cr}_{\mathrm{p}}, \mathrm{Cu}_{\mathrm{p}}$ and $\mathrm{Ni}_{\mathrm{p}}$ concentrations coincided with high POC values, as previously observed by Strady et al. (2017a) suggesting that organic matter might be an important factor affecting those metal distributions. The decrease and variation of $\mathrm{Cr}_{\mathrm{p}}, \mathrm{Cu}_{\mathrm{p}}$ and $\mathrm{Ni}_{\mathrm{p}}$ concentrations, at the riverine part and the beginning of estuary (Fig. 4c, e and 4f), may be thus related to the organic matter degradation.

\subsection{Relationship between TSS and total trace metal concentrations}

To assess the control of TSS concentrations on metal transfer in the Can Gio Estuary, the total metal concentrations in a volume of water (i.e. the particulate concentrations, expressed in $\mathrm{mg} \mathrm{L}^{-1}$, plus dissolved concentrations) were calculated (Strady et al., 2017b; 

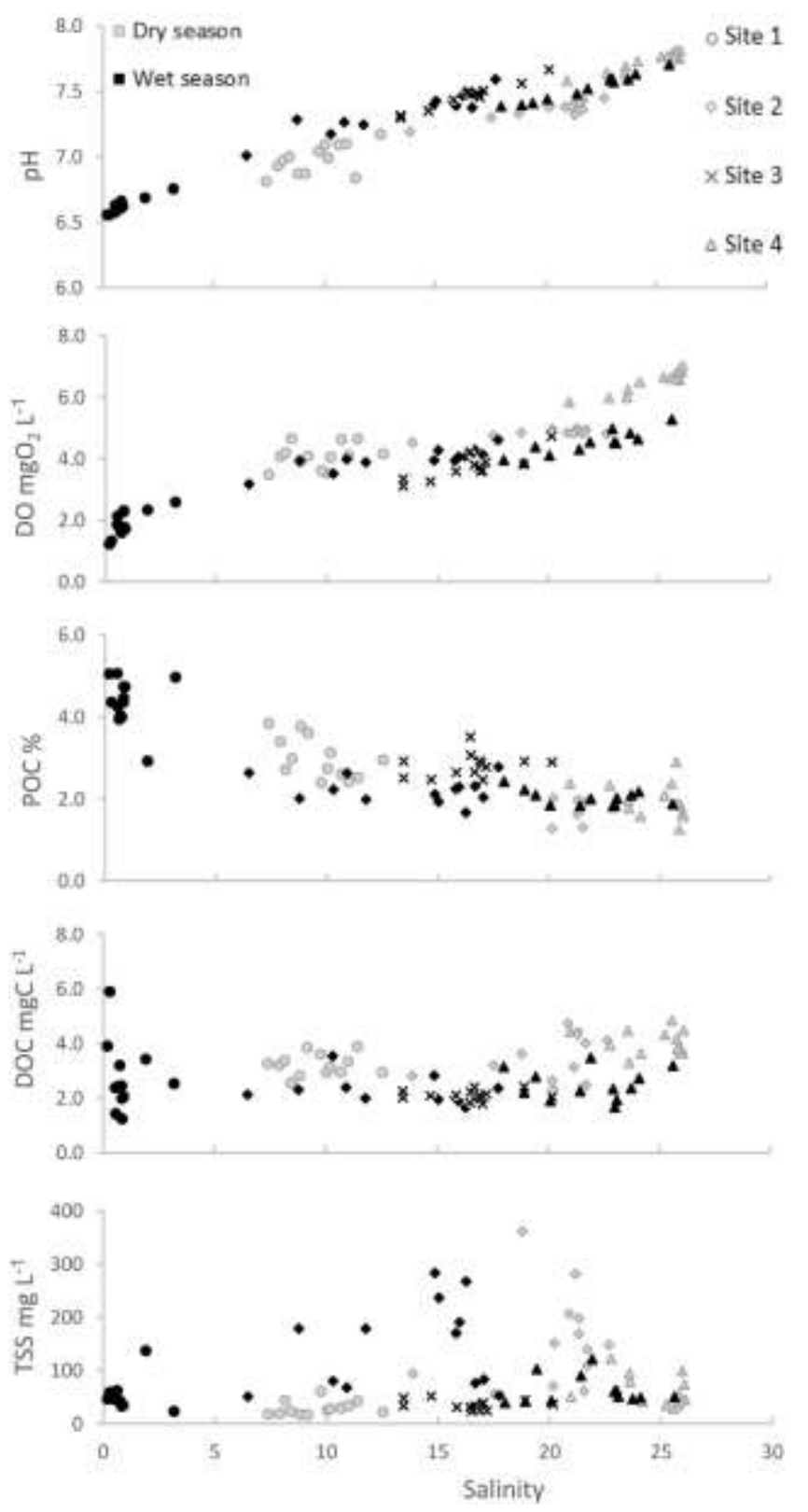

Fig. 2. Spatio-temporal variations in $\mathrm{pH}, \mathrm{DO}, \mathrm{POCDOC}$ and TSS along the salinity gradient during the dry and the wet seasons.

Wang et al., 2016) and expressed in $\mathrm{mg} \mathrm{L}^{-1}$ (ig. 3). All total metal concentrations increased with increasing TSS concentrations along the estuary $(r>0.95, p<.01$ for all metals during the dry season, and $\mathrm{r}>0.9$ for $\mathrm{Mn}, \mathrm{Fe}, \mathrm{Cr}, \mathrm{Ni}$ and $\mathrm{Pb} ; \mathrm{r}^{1 / 4} 0.80$ for $\mathrm{Co} ; \mathrm{r}^{1 / 4} 0.75$ for $\mathrm{Cu}$ and $\mathrm{r} 1 / 40.46$ for As; $\mathrm{p}<.01$ during the rainy season) supporting the fact that the total metal concentrations transfer in the Can Gio Estuary is controlled by the change of TSS concentrations whatever the season, like in the Mekong Delta, Vietnam (Strady et al., 2017b), in the Huanghe River Estuary, China (Wang et al., 2016) or in the Changiiang River Estuary, China (Yang et al., 2014). However, for a given TSS concentration, total concentrations in $\mathrm{Fe}, \mathrm{Cr}, \mathrm{Ni}$ and $\mathrm{Pb}$ were higher during the monsoon than the dry season (Fig. 3) suggesting enhanced metal transport from land to sea during the monsoon. The particulate phase was the dominant one for $\mathrm{Fe}, \mathrm{Cr}$ and $\mathrm{Co}$, representing more than $99 \%$ of the total for $\mathrm{Fe}, 75 \mathrm{e} 99 \%$ for $\mathrm{Cr}$ and $70 \mathrm{e} 98 \%$ for $\mathrm{Co}$, while the percentage of $\mathrm{Ni}_{\mathrm{p}}, \mathrm{Cu}_{\mathrm{p}}, \mathrm{Asp}_{\mathrm{p}}, \mathrm{Pb}_{\mathrm{p}}$ and
$\mathrm{Mn}_{\mathrm{p}}$ varied from 22 to $91 \%, 28$ e95\%, 13e94\%, 24e99\% and $29 \mathrm{e} 99 \%$, respectively. This result suggests different partitioning between particulate and dissolved metal phases during their transit along the Can Gio mangrove Estuary.

\subsection{Trace metal partitioning in the estuarine zone}

\subsubsection{Iron}

Along the salinity gradient, Fep varied from 35,276 to 55,302 $\mathrm{mg} \mathrm{kg}^{-1}$ during the monsoon, and from 13,917 to $41,328 \mathrm{mg} \mathrm{kg}^{-1}$ during the dry season with minimum values reached at the seaside of the estuary (Fig. $4 \mathrm{a})$. These lower values during the dry season could be attributed to the dilution with the sea water (i.e. $\mathrm{Fe}_{\mathrm{p}}$ concentrations of $15,000 \mathrm{mg} \mathrm{kg}^{-1}$ in coastal zones of the Pacific Ocean (Hatje et al., 2001)). During the monsoon, dilution was not observed, probably due to intense leaching of Fe from the surrounded mangrove soils, Fe being a rich element of mangrove soils (Marchand et al., 2006; Miola et al., 2016; Noe $€ \underline{1 \quad \text { et al., }}$ 2014). The $\mathrm{Fe}_{\mathrm{D}}$ varied between 1.01 and

$3.3 \mathrm{mg} \mathrm{L}^{-1}$ during the dry season and $1.6 \mathrm{e} 5.0 \mathrm{mg} \mathrm{L}^{-1}$ during the rainy season. Along the salinity gradient, $\mathrm{Fe}_{\mathrm{D}}$ showed a nonconservative behavior with additive concentrations at mid salinity (site 2 and 3) (Fig. 4a, supplementary data 1 and 2). During the dry season at site 2 , these higher concentrations might be attributed first to the contribution of the pore-water inputs from mangrove sediments, as observed in mangrove estuaries like in Australia (Santos et al., 2011). These authors reported extremely high dissolved iron concentration up to $374 \mathrm{mg} \mathrm{L}^{-1}$ in pore-water. They also evidenced that iron in surface water originated from mangrove soils by pore-water discharge, using radio-isotopes (Radon, ${ }^{222} \mathrm{Rn}$ ). In fact, mangrove soils can be rich in dissolved iron as described in the Pai Matos mangrove system, Brazil (Otero et al., 2009) or in the French Guiana mangrove (Marchand et al., 2006). This richness result from the alternation of different redox processes, notably iron oxide reduction and iron sulphide oxidation, leading both to the release of dissolved iron in porewaters, which can thus be exported to adjacent ecosystems through pore-water seepage (Deborde et al., 2015; Sanders et al., 2015). Secondly, we assumed that irregular inputs from the shrimp farms might also be a source of dissolved iron concentration to the water column as observed in the Estuaries of EastHainan, China (Fu et al., 2013). The Fed concentrations were influenced by $\mathrm{pH}$ changes, associated to the cultivation cycles (Azevedo et al., 2009), reaching approximately $2 \mathrm{mg} \mathrm{L}^{-1}$ in ponds on acid sulfate soils (Jayasinghe et al., 2010). Unfortunately, we were not able to determine the Fed concentrations at site 3 during the dry season, which was only surrounded by mangrove forest. During the rainy season, scattered FeD were also measured at site 2 and at site 3 at both ebb and flood tides, which may be related to pore-water releases from mangrove sediments, aquaculture ponds or runoff from the surrounding watershed. Along the Can Gio

mangrove Estuary, $\log \mathrm{K}_{\mathrm{D}}^{\mathrm{Fe}}$ was stable whatever the season, ranging from 6.1 to 7.6 (Fig. 4a). The absences of significant correlations between $\log \mathrm{K}_{\mathrm{De}}^{\mathrm{Fe}}$ and salinity, pH, DO, DOC, POC or TSS do not allow us to better characterize Fe partitioning along this mangrove estuary.

\subsubsection{Manganese}

$\mathrm{Mn}_{\mathrm{p}}$ ranged from 402 to $1055 \mathrm{mg} \mathrm{kg}^{-1}$ during the dry season and from 397 to $922 \mathrm{mg} \mathrm{kg}^{-1}$ during the monsoon along the salinity gradient (Fig. 4b), showing an absence of seasonal effect. These values were in the same range than those measured at the upstream site during the rainy season, and in tropical estuaries like the Tanshui Estuary, Northern Taiwan (Fang and Lin, 2002). The high $\mathrm{Mn}_{\mathrm{p}}$ fluctuations and its absence of conclusive distribution along the 

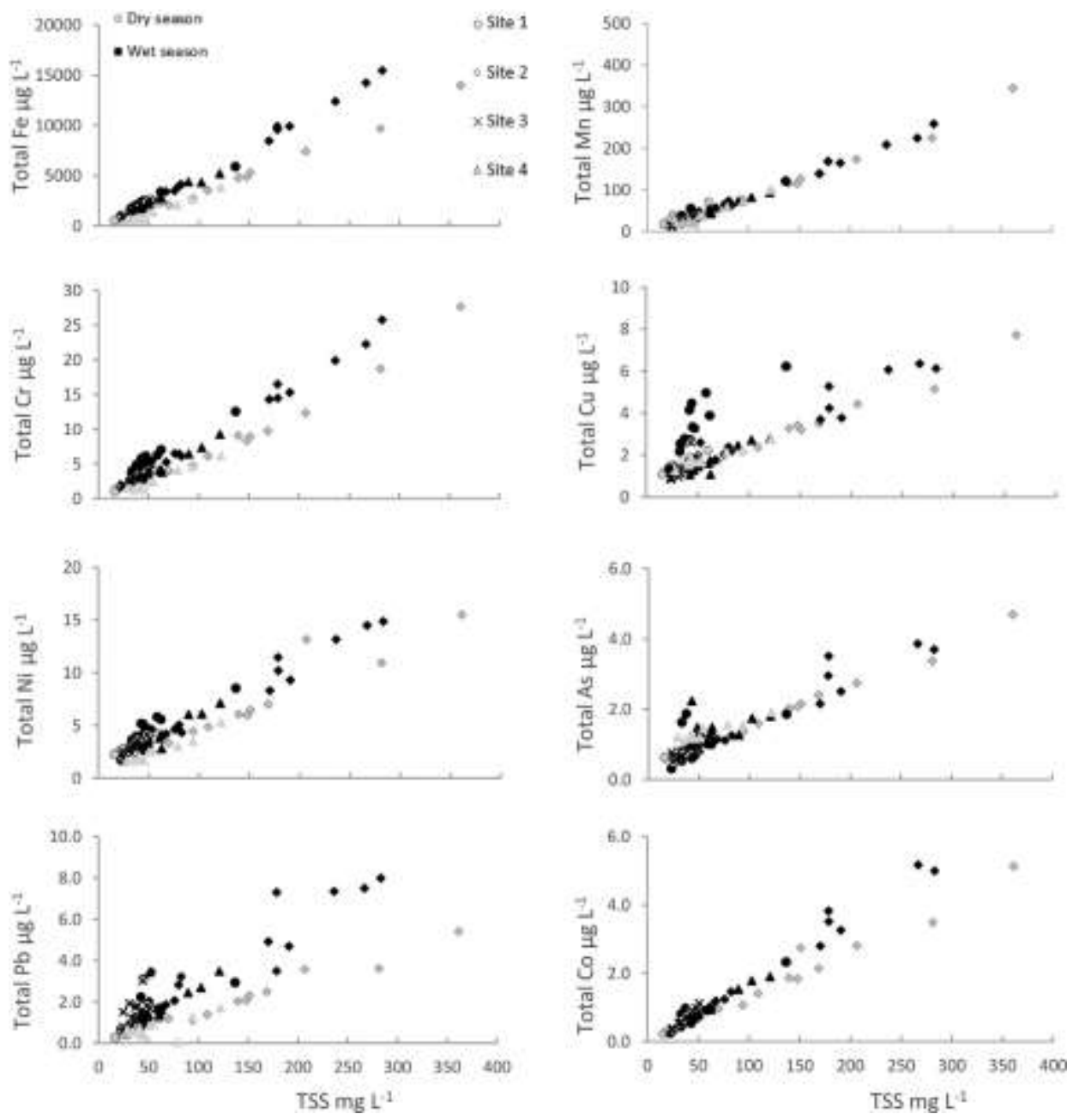

Fig. 3. Relationship between the total metal concentrations (i.e. dissolved plus particulate metal concentrations, expressed in $\mathrm{mgL}^{-1}$ ) of $\mathrm{Fe}, \mathrm{Cr}$, $\mathrm{Ni}$, $\mathrm{Pb}, \mathrm{Mn}, \mathrm{Cu}, \mathrm{As}, \mathrm{Co}$ and $\mathrm{TSS}$ concentration during the dry and the wet seasons.

salinity gradient indicated that the $\mathrm{Mn}_{\mathrm{p}}$ distribution in the Can Gio Estuary was not dominated by a simple mixing of the two end members, and might be influenced by biogeochemical processes. The $\mathrm{Mn}_{\mathrm{D}}$ varied between 15.2 and $0.93 \mathrm{mg} \mathrm{L}^{-1}$ and 12.5 to $0.98 \mathrm{mgL}^{-1}$ during the dry and the rainy season, respectively (Fig. $4 \mathrm{~b}$, supplementary data 1 and 2). Additionally, it decreased along the salinity gradient exhibiting a non-conservative subtractive behavior whatever the season. Both in laboratory experiments (Hatje et al., 2003) and in the field (Fang and Lin, 2002), it was observed that DO increase can result in MnD adsorption onto particles surface by the oxidation of dissolved Mn (II) to insoluble Mn (III) and Mn (IV) (hydr)-oxides. Log $\mathrm{K}_{\mathrm{D}}^{\mathrm{Mn}}$ increased from 4.0 to 5.8 along the salinity gradient whatever the seasons (Fig. 4 b) exhibiting good correlation with both $\mathrm{DO}$ and $\mathrm{pH}$ (Fig. $5 \mathrm{a}$ and b), suggesting that Mn partitioning is probably affected by the change of oxygenation in the estuary. During the dry season, higher MnD were measured at site 2, similarly to $\mathrm{Fe}_{\mathrm{D}}$, and could also originate from mangrove sediment porewaters (Holloway et al., 2016; Sanders et al., 2015) or shrimp ponds effluents (Inoue and Asano, 2013). During the rainy season, $\mathrm{Mn}_{\mathrm{D}}$ presented scattered values at flood tide that might be related to runoff inputs of the adjacent watershed. Consequently, Mn dynamic along the estuary was strongly influenced by geochemical processes, mainly $\mathrm{Mn}$ precipitation resulting from oxygenation and $\mathrm{pH}$ changes with water mixing.

\subsubsection{Chromium}

The $\mathrm{Cr}_{\mathrm{P}}$ ranged from 25 to $79 \mathrm{mg} \mathrm{kg}^{-1}$ during the dry season and from 57 to $94 \mathrm{mg} \mathrm{kg}^{-1}$ during the rainy season (Supplementary data 1 and 2), showing seasonal variations and decreasing concentrations along the salinity gradient (Fig. 4c). The $\mathrm{Cr}_{\mathrm{p}}$ in the estuarine zone were slightly lower than in the riverine part (upstream site during the rainy season), while the $\mathrm{Cr}_{\mathrm{p}}$ at the seaside of the estuary were close to the $\mathrm{Cr}_{\mathrm{p}}$ reported in the coastal area of South China Sea (Cenci and Martin, 2004). Therefore, the $\mathrm{Cr}_{\mathrm{p}}$ concentrations decrease along the salinity gradient might be attributed to both dilution with seawater containing low $\mathrm{Cr}_{\mathrm{p}}$ and to its desorption processes during organic matter degradation in the estuary, Cr having a strong affinity for organic matter (Masscheleyn et al., 1992). We observed that later process may play an important role on $\mathrm{Cr}_{\mathrm{p}}$ distribution during the rainy season (i.e. a positive correlation observed between $\mathrm{Cr}_{\mathrm{p}}$ and POC, $\mathrm{r} 1 / 40.71$ ) and a minor role during the dry season $\left(\mathrm{r}^{1} / 40.53\right)$, affecting also $\mathrm{Cr}$ partitioning (Fig. 5c). The $\mathrm{Cr}_{\mathrm{D}}$ showed distinct behaviors along the salinity gradient between seasons: i) conservative distribution with gradually $\mathrm{Cr}_{\mathrm{D}}$ increase seaward during the dry season, and ii) non-conservative with a gain of $\mathrm{Cr}_{\mathrm{D}}$ at mid salinity during the rainy season (Fig. 4c, supplementary data 1 and 2). Scattered and higher $\mathrm{Cr}_{\mathrm{D}}$ at site 2 and site 3 observed during the monsoon might be originated from the same sources as $\mathrm{Fe}_{\mathrm{D}}$ (positive correlation 

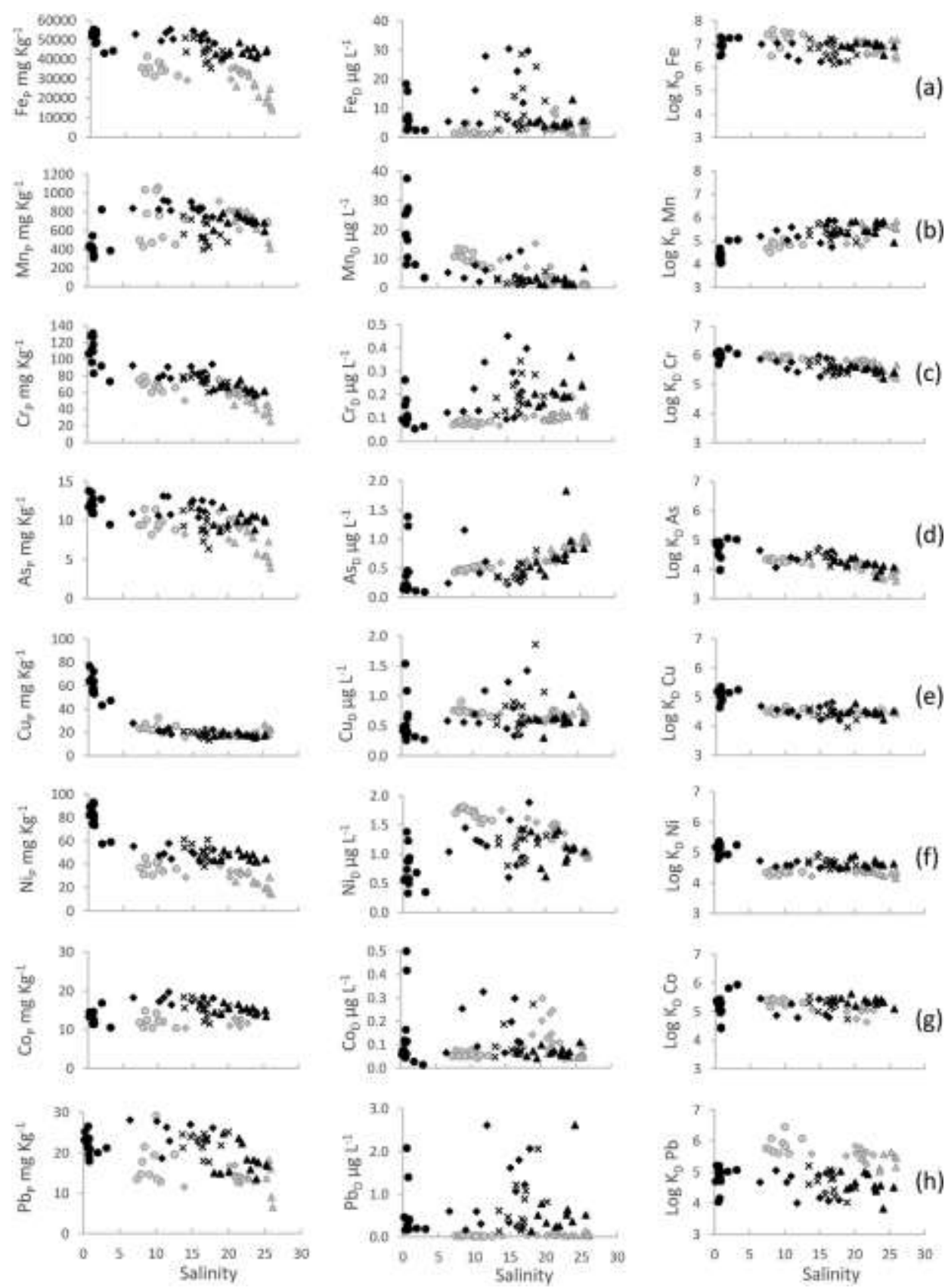

Fig. 4. Distribution of dissolved, particulate, log Kd of metals in the Can Gio mangrove estuary during the dry (gray dots) and the wet seasons (black dots), with circles, squares, multiplication signs and triangles representing the site 1, site 2, site 3 and site 4 respectively: $\mathrm{Fe}(\mathrm{a}), \mathrm{Mn}(\mathrm{b}), \mathrm{Cr}(\mathrm{c}), \mathrm{As}(\mathrm{d}), \mathrm{Cu}(\mathrm{e}), \mathrm{Ni}(\mathrm{f}), \mathrm{Co}(\mathrm{g})$ and $\mathrm{Pb}(\mathrm{h})$.

between $\mathrm{Cr}_{\mathrm{D}}$ and FeD; Fig. 5 f), i.e. mangrove sediment pore-water releases (Szymczycha et al., 2016), runoff and/or shrimp pond effluents inputs. Along the estuary, $\log \mathrm{K}_{\mathrm{D}}^{\mathrm{Cr}}$ decreased from 6.2 to 5.2 and presented a low variation range. The combination of $\mathrm{Cr}_{\mathrm{D}}$ increase, $\log \mathrm{K}_{\mathrm{D}}^{\mathrm{Cr}}$ decrease from the upstream site to the seaside and the positive correlation between Log $\mathrm{K}_{\mathrm{D}}^{\mathrm{Cr}}$ and POC (Figs. $4 \mathrm{c}$ and $\underline{5}$ d) confirm the $\mathrm{Cr}$ desorption from particulate organic matter during the water transit in the estuary. We suggest that the oxidation level may also influence $\mathrm{Cr}$ partitioning as evidenced by the negative correlation observed between $\log \mathrm{K}^{\mathrm{Cr}}$ and $\mathrm{DDO}$

(Fig. 5e). Thus, $\mathrm{Cr}$ partitioning in the Can Gio mangrove Estuary was controlled by physical mixing and also biochemical processes, notably $\mathrm{OM}$ decomposition and increased oxygenation along the estuary.

\subsubsection{Arsenic}

The Asp varied from 6.4 to $13.8 \mathrm{mg} \mathrm{kg}^{-1}$ during the rainy season, and from 3.9 to $11.5 \mathrm{mg} \mathrm{kg}^{-1}$ during the dry season. Values were stable along the salinity gradient during the rainy season and presented a drop of concentrations at site 4 during the dry season (Fig. 4d). The concentrations at the seaside during the dry season were in the same range than those measured in the coastal zone of South China Sea (Cenci and Martin, 2004) and in the Bohai Sea (Wang et al., 2016). The Asp distribution in the Can Gio mangrove Estuary reflected thus the water mixing between the river and the sea end-members but also biogeochemical processes. Along the estuary, Asp exhibited a strong correlation to $\mathrm{FeP}(\mathrm{r}>0.8$, for both seasons, Fig. 5g) implying that $\mathrm{Fe}_{\mathrm{p}}$ was the main carrier phase of As (Strady et al., 2017a) and an important factor controlling Asp 

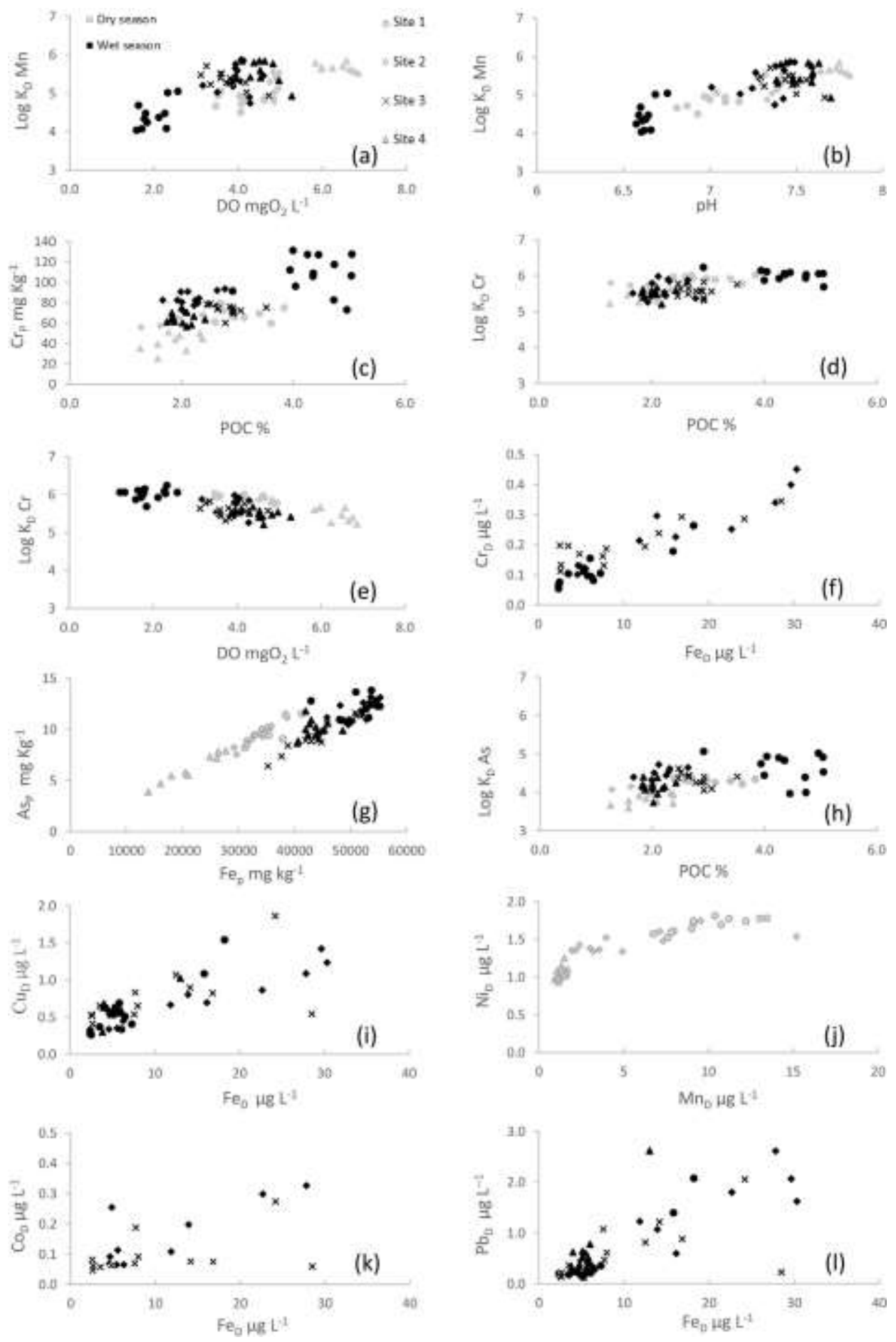

Fig. 5. Interrelations between dissolved metal concentrations and relationships between $\log \mathrm{K}_{\mathrm{D}}$ of metal with physico-chemical parameters during the dry and the wet seasons: (a)

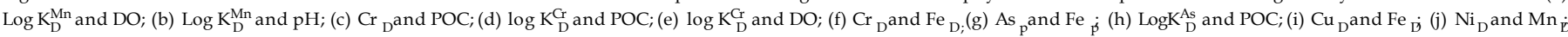
(k) CoDand Fed; (l) PbD and Fed.

distribution in the estuary. Both metals probably had a terrigenous origin (Cances et al., 2005; Oursel et al., 2014). Actually in Vietnam, many soils are naturally enriched in As, which is a public health problem for the local populations (Gustafsson and Tin, 1994; Nguyen et al., 2016; Phuong et al., 2010). Along the estuary, As concentrations increased from 0.5 to 0.95 during the dry season and from 0.15 to $0.65 \mathrm{mg} \mathrm{L}^{-1}$ during the rainy season, which might be caused by dilution with sea water i.e. $1.5 \mathrm{mgL}^{-1}$ of AsDin the
Bohai Sea (Wang et al., 2016) and probably by As release during degradation of organoarsenic compounds from particulate phase (i.e. negative correlations were observed between AsDand POC, $\mathrm{r} 1 / 40.64)$. This hypothesis is supported by the $\log \mathrm{As}_{\mathrm{S}}^{\mathrm{As}} \mathrm{dec}$ ease along the salinity gradient, especially from mid salinity (ig. 4d) and by

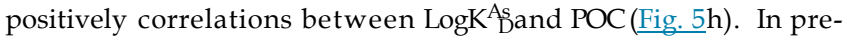
vious studies, some authors noticed that dissolved organic carbon plays an important role of As partitioning between dissolved and 
particulate phase because it can strongly interact with As species (Bauer and Blodau, 2006; Liu and Cai, 2010; Yanan et al., 2017). In the Can Gio mangrove estuary, however, we observed the correlation coefficients between As concentrations and DOC being low during the dry season $(r<0.4)$ and very low during the rainy season $(p>.05)$. As a consequence, we suggest that the As-DOCcomplexation may occur as a minor processes and possibly causing $\log K_{D}^{A s}$ decrease along the estuary. The AsD distributions presented conservative to non-conservative behavior with slightly subtractive concentrations at mid salinity during both seasons (Fig. 4d), which might be caused by the AsD adsorption onto particle phase containing rich (hydr)oxide $\mathrm{Fe}_{\mathrm{p}}$ (Lenoble et al., 2013). We also noticed low LogKAs values at the upstream site during the ebb tide, which could be related to the Sai Gon River inputs containing high AsD. In conclusion, As partitioning in the Can Gio Estuary was affected by both physical and biogeochemical processes, mainly organic matter decomposition.

\subsubsection{Copper}

During both seasons, Cupvaried between 13 and $33 \mathrm{mg} \mathrm{kg}^{-1}$ (Fig. 4e, supplementary data 1 and 2) and presented stable values in the estuarine part ( 5 e 25 salinity), as observed in the East Hainan, China (Fu et al., 2013) and in the Pearl River Estuary, South China (Zhang et al., 2013). Adrop of Cupwas observed between the riverine part (e.g. 43 e $77 \mathrm{mg} \mathrm{kg}^{-1}$, upstream site during the rainy season) and the beginning of the estuary. This loss of $\mathrm{Cu}_{\mathrm{p}}$ at the fresh water - estuary interface could be related to intense organic matter degradation processes leading to desorption reaction due to the decomposition of organo-copper complexes; the urban water was characterized by both high POC and $\mathrm{Cu}_{\mathrm{p}}$. The higher $\log \mathrm{K}_{\mathrm{D}}^{\mathrm{Cu}}$ at the upstream site during the monsoon (Fig. 4e) confirmed those hypothesis. The CuD varied from 0.5 to 0.9 and $0.3 \mathrm{e} 1.8 \mathrm{mg} \mathrm{L}^{-1}$ during the dry season and the monsoon, respectively, with a high variation range and no clear evolution along the salinity gradient. However, punctual elevated $\mathrm{Cu}_{\mathrm{D}}$ at site 2 and site 3 were measured during the monsoon (Fig. 4e) and were positively correlated to $\mathrm{Fe}_{\mathrm{D}}$ (r $1 / 40.73$, Fig. 5i) possibly suggesting the same sources as for Fe: inputs from adjacent ecosystems. However, these punctual $\mathrm{Cu}_{\mathrm{D}}$ inputs did not seem to affect the Cu partitioning, as evidenced by the stable $\log \mathrm{K}_{\mathrm{D}}^{\mathrm{Cu}}$ along the estuary (Fig. $\left.4 \mathrm{e}\right)$. These results suggest the biogeochemical processes might be minor factors influencing the $\mathrm{Cu}$ partitioning in this environment.

\subsubsection{Nickel}

The $\mathrm{Ni}_{\mathrm{p}}$ distribution along the salinity gradient differed between seasons. During the rainy season, $\mathrm{Ni}_{\mathrm{p}}$ varied from 61 to $38 \mathrm{mg} \mathrm{kg}^{-1}$, with stable concentrations in the estuarine part, which were approximately 2efold lower than in the riverine part (Fig. 4f, supplementary data 1 ). At the river end-member, high $\mathrm{Ni}_{\mathrm{p}}$ were suggested to be related to the high POC concentrations. Like for $\mathrm{Cu}$, the decrease of $\mathrm{Ni}_{\mathrm{p}}$ at the river-estuary interface may result from $\mathrm{Ni}_{\mathrm{p}}$ desorption due to organic matter degradation. The $\mathrm{Ni}$, varied from 0.3 to $1.8 \mathrm{mg} \mathrm{L}^{-1}$ along the estuary with scattered concentrations. The absences of correlations between $\mathrm{Ni}_{\mathrm{D}}$ and physicochemical parameters or TSS or other metals do not allow us to identify the origin of scattered NiDconcentrations. Log $\mathrm{K}^{\mathrm{Ni}} \mathrm{w}$ कs stable along the salinity gradient, except a slight decrease at the river-estuary interface ( $\mathrm{Fig}$. $4 \mathrm{f})$, inferring that $\mathrm{Ni}$ was poorly reactive in the Can Gio mangrove Estuary during the rainy season. During the dry season, $\mathrm{Ni}_{\mathrm{p}}$ slightly decreased along the salinity gradient and dramatically dropped to minimum values at the mouth of the estuary, from $45.6 \mathrm{mg} \mathrm{kg}^{-1}$ to $14.4 \mathrm{mg} \mathrm{kg}^{-1}$ (Fig. $4 \mathrm{f}$, supplementary data 1). This phenomena might be induced by the marine dilution, the coastal area of South China Sea containing low $\mathrm{Ni}_{\mathrm{p}}, 12 \mathrm{mg} \mathrm{kg}^{-1}$ (Cenci and Martin, 2004). The decrease of $\mathrm{Ni}_{\mathrm{p}}$ caused by sea water dilution was previously observed in the Tanshui Estuary, Northern Taiwan (Fang and Lin, 2002) and in the East Hainan, China (Fu et al., $\underline{2013})$. The gradual $\mathrm{Ni}_{\mathrm{D}}$ decrease during the dry season $\left(1.81 \mathrm{mg} \mathrm{L}^{-1}\right.$ to $0.93 \mathrm{mg} \mathrm{L}^{-1}$ ) from site 1 to site 4 could be also related to sea water dilution, NiD were lower than $0.3 \mathrm{mg} \mathrm{L}^{-1}$ in the coastal area of South China Sea (Cenci and Martin, 2004). This decrease can also be related to co-precipitation of $\mathrm{Ni}$ and $\mathrm{Mn}$ onto solid phase (i.e. a positive correlation between $\mathrm{Ni}_{\mathrm{D}}$ and $\mathrm{Mn}_{\mathrm{D}}, \mathrm{r} 1 \frac{1}{4} 0.88$, Fig. $5 \mathrm{j}$ ), like previously observed in the Port Curtis Estuary, Australia (Angel et al., 2010) and in Yangtze River Estuary (Wen et al., 2013). During both seasons, the stability of Log $\mathrm{K}_{\mathrm{D}}^{\mathrm{Ni}}$ suggests that $\mathrm{Ni}$ was poorly reactive in the estuary. The physical mixing was thus the main factor controlling the $\mathrm{Ni}$ partitioning in the Can Gio mangrove Estuary.

\subsubsection{Cobalt and lead}

Because of their similar distributions in dissolved, particulate concentrations and partitions along the studied estuary, $\mathrm{Co}$ and $\mathrm{Pb}$ concentrations are presented and discussed together. The $\mathrm{Pb}_{\mathrm{p}}$ presented scattered values close to $21 \mathrm{mg} \mathrm{kg}^{-1}$ and $15 \mathrm{mg} \mathrm{kg}^{-1}$ during the monsoon and the dry season respectively, while $\mathrm{Co}_{\mathrm{p}}$ were varied around $13 \mathrm{mg} \mathrm{kg}^{-1}$ for both seasons (Fig. $4 \mathrm{~g}$ and $\mathrm{h}$, supplementary data 1 and 2). Those scattered concentrations were often observed in tropical estuaries, like in the Wenchang/Wenjiao River Estuary, East-Hainan, China (Fu et al., 2013) and in the Changjiang Estuary, Eastern China (Wang and Liu, 2003). The physico-chemical parameters had a limited effect to $\mathrm{Co}_{\mathrm{p}}$ and $\mathrm{Pb}_{\mathrm{p}}$ distributions (e.g. no significant correlation with $\mathrm{pH}, \mathrm{DO}$ or POC), implying that biogeochemical processes have a restricted control on the $\mathrm{Co}$ and $\mathrm{Pb}$ distribution in the estuary. The Co presented baseline concentration close to $0.05 \mathrm{mg} \mathrm{L}^{-1}$ during both seasons whereas the $\mathrm{Pb}_{\mathrm{D}}$ were closed to $0.3 \mathrm{mg} \mathrm{L}^{-1}$ and $0.03 \mathrm{mg} \mathrm{L}^{-1}$ and the dry season, respectively, exhibiting a seasonal effect. The higher measured $\mathrm{Pb}_{\mathrm{D}}$ during the rainy season might be attributed to intense leaching from mangrove soil (Defew et al., 2005) and/or to $\mathrm{Pb}$ enrichment by atmospheric deposition (Hien et al., 1997, 1999). Along the salinity gradient, both $\mathrm{COD}$ and $\mathrm{Pb}_{\mathrm{D}}$ showed nonconservative additive behaviors (Fig. $4 \mathrm{~g}$ and h), as previously observed in the Mekong delta (Cenci and Martin, 2004) and in the Changjiang Estuary, Eastern China (Wang and Liu, 2003). Scattered $\mathrm{CoD}_{\mathrm{D}}$ and $\mathrm{Pb}_{\mathrm{D}}$ concentrations were observed at site 2 and site 3 during both flood and ebb tides in the rainy season that suggested similar sources between those metals and $\mathrm{Fe}_{\mathrm{D}}$ (significant correlations with FeD:r 1/40.56 for CoD and $\mathrm{r} 1 / 40.77$ for PbD, Fig. $5 \mathrm{k}$ and 1). In the Southern Baltic Sea, a significant pore-water dischargealong the coastal area was reported to be a source of dissolved $\mathrm{Co}$ and $\mathrm{Pb}$ (Szymczycha et al., 2016). Log $\mathrm{K}^{\mathrm{Co}}$ ond Log $\mathrm{K}^{\mathrm{Pb}} \mathrm{w}_{\mathrm{B}}$ re stable and scattered along the estuary during both seasons but not correlated to any physico-chemical parameters, suggesting a poor reactivity (Fig. $4 \mathrm{~g}$ and h). The scattered $\log \mathrm{K}^{\mathrm{C}}$ Dand $\log \mathrm{K}^{\mathrm{Pb}}$ ovidenced thus that the contribution of extra sources played an important role in $\mathrm{Co}$ and $\mathrm{Pb}$ distributions in the Can Gio Estuary.

\section{Conclusions}

The Can Gio mangrove Estuary is a dynamic environment at the edge between the biggest City in Vietnam and the South China Sea. The water delivered to the estuary during the rainy season was acidic, almost anoxic, and rich in organic matter and in trace metals, evidencing strong anthropogenic pressure on the ecosystem. We suggest that during the monsoon season, heavy rainfall induced increased runoff and soil leaching, resulting in enhanced trace metal inputs to the estuary, both in particulate and dissolved phases. However, as soon as the trace metals enter the estuary, their distribution and partitioning changed due to the physical mixing 
with seawater and/or biogeochemical processes. The first parameter controlling metal dynamics and transport from Ho Chi Minh City to the South China Sea was the concentration of suspended solids, which can vary as a function of tide and season. Strong correlations were measured between total trace metal concentrations and TSS, whatever the element, but they did not explain the whole variability of trace metal dynamics along the estuary. Organic matter played also a key role on these dynamics. First, we suggest that the elevated inputs of $\mathrm{Cu}_{\mathrm{p}}, \mathrm{Ni}_{\mathrm{p}}$ and $\mathrm{Cr}_{\mathrm{p}}$ were related to the high POC concentrations at the upstream site during the monsoon season. Then, OM decomposition along the estuary resulted in metal release in the dissolved phase, with increasing concentrations with the salinity gradient, specifically for As and $\mathrm{Cr}$. Conversely, concentrations of other dissolved elements decreased along the salinity gradient, either due to water mass mixing, or geochemical processes, which was the case for $\mathrm{Mn}$. Fe, $\mathrm{Co}$ and $\mathrm{Pb}$ which were poorly reactive during their transit, as evidenced by the absence of any specific correlation between their $\log K_{D}$ and the physico-chemical parameters studied. For the latter metals, water mass mixing was suggested to be the main factor driving their distribution along this mangrove Estuary. Regarding the potential impacts of extra sources on metal partitioning like: i) pore-waters flushed out from mangrove soils at low tide, ii) runoff from adjacent soils, or iii) shrimp pond effluents, a further detailed investigation should be carried out at sites without freshwater discharge to get a better assessment of their role in trace metals dynamic along the estuary. Furthermore, trace metal geochemistry should be studied in the whole ecosystem (e.g. mangrove soils, trees, animals) and not only in the water column, to understand their potentially bioavailability and ecologically risks.

\section{Acknowledgements}

Nguyen Thanh-Nho received a BEST scholarship grant from IRD to develop his research. The authors acknowledge the people who helped them to do the fieldtrips, specifically the Can Gio management board and fishermen. The study was funded by the PEPS CNRS-IRD "Mangrove", the Region Auvergne Rho nes Alpes CMIRA grants 'Saigon River: la ville et le fleuve'.

\section{Appendix A. Supplementary data}

Supplementary data related to this article can be found at https://doi.org/10.1016/j.chemosphere.2017.12.189.

\section{References}

Abril, G., Nogueira, M., Etcheber, H., Cabeçadas, G., Lemaire, E., Brogueira, M.J., 2002. Behaviour of organic carbon in nine contrasting european estuaries. Estuar. Coast Shelf Sci. 54 (2), $241 \mathrm{e} 262$.

Acosta, J., Jansen, B., Kalbitz, K., Faz, A., Martínez-Martínez, S., 2011. Salinity increases mobility of heavy metals in soils. Chemosphere 85 (8), $1318 \mathrm{e} 1324$.

Angel, B., Hales, L.T., Simpson, S.L., Apte, S.S., Chariton, A.A., Shearer, D., Jolley, D.F., 2010. Spatial variability of cadmium, copper, manganese, nickel and zinc in the Port Curtis Estuary, Queensland, Australia. Mar. Freshw. Res. 61 (2), 170 e 183.

Azevedo, A., Holanda, J., Scudelari, A., 2009. Dynamic of heavy metals in the shrimp farm environment. J. Coast Res. $1174 \mathrm{e} 1178$.

Bauer, M., Blodau, C., 2006. Mobilization of arsenic by dissolved organic matter from iron oxides, soils and sediments. Sci. Total Environ. 354 (2 e 3), $179 \mathrm{e}$ 190.

Benoit, G., Oktay-Marshall, S., Cantu, A., Hood, E., Coleman, C., Corapcioglu, M., Santschi, P., 1994. Partitioning of $\mathrm{Cu}, \mathrm{Pb}, \mathrm{Ag}, \mathrm{Zn}, \mathrm{Fe}, \mathrm{Al}$, and $\mathrm{Mn}$ between filterretained particles, colloids, and solution in six Texas estuaries. Mar. Chem. 45 $(4), 307 \mathrm{e} 336$

Cances, B., Juillot, F., Morin, G., Laperche, V., Alvarez, L., Proux, O., Hazemann, J.-L., Brown, G., Calas, G., 2005. XAS evidence of as (V) association with iron oxyhydroxides in a contaminated soil at a former arsenical pesticide processing plant. Environ. Sci. Technol. 39 (24), 9398 e 9405.

Cang, L.T., Czerniak, P., Thanh, N.C., Schwarzer, K., Ricklefs, K., 2007. Suspended Sediment Dynamics in Mangrove Areas, Dong Tranh Estuary, Can Gio Mangrove Forest, Ho Chi Minh City, Southern Vietnam. Annual Report of FY 2007. The Core
University Program between Japan Society for the Promotion of Science (JSPS) and Vietnamese Academy of Science and Technology (VAST), pp. $439 \mathrm{e} 450$.

Cenci, R.M., Martin, J.M., 2004. Concentration and fate of trace metals in Mekong River delta. Sci. Total Environ. 332 (1 $\mathrm{e}$ 3), $167 \mathrm{e} 182$

Chu, H., Chen, N., Yeung, M., Tam, N., Wong, Y., 1998. Tide-tank system simulating mangrove wetland for removal of nutrients and heavy metals from wastewater. Water Sci. Technol. 38 (1), 361 e 368.

Costa-Boddeker, S., Hoelzmann, P., Thuyen, L.X., Huy, H.D., Nguyen, H.A., Richter, O., Schwalb, A., 2017. Ecological risk assessment of a coastal zone in Southern Vietnam: spatial distribution and content of heavy metals in water and surface sediments of the Thi Vai Estuary and Can Gio Mangrove Forest. Mar. Pollut. Bull. $114(2), 1141 \mathrm{e} 1151$.

de Souza Machado, A.A., Spencer, K., Kloas, W., Toffolon, M., Zarfl, C., 2016. Metal fate and effects in estuaries: a review and conceptual model for better understanding of toxicity. Sci. Total Environ. 541, $268 \mathrm{e} 281$.

Deborde, J., Marchand, C., Molnar, N., Patrona, L., Meziane, T., 2015. Concentrations and fractionation of carbon, iron, sulfur, nitrogen and phosphorus in mangrove sediments along an intertidal gradient (Semi-Arid climate, New Caledonia). I. Mar. Sci. Eng. 3 (1), 52 e 72.

Defew, L.H., Mair, J.M., Guzman, H.M., 2005. An assessment of metal contamination in mangrove sediments and leaves from Punta Mala Bay, Pacific Panama. Mar. Pollut. Bull. 50 (5), 547e 552.

Dittmar, T., Lara, R.J., 2001. Driving forces behind nutrient and organic matter dynamics in a mangrove tidal creek in north Brazil. Estuar. Coast Shelf Sci. 52 (2) $\underline{249}$ e 259 .

Elliott, M., McLusky, D.S., 2002. The need for definitions in understanding estuaries. Estuar. Coast Shelf Sci. 55 (6), 815 e 827.

Etcheber, H., Taillez, A., Abril, G., Garnier, J., Servais, P., Moatar, F., Commarieu, M.-V., 2007. Particulate organic carbon in the estuarine turbidity maxima of the Gironde, Loire and Seine estuaries: origin and lability. Hydrobiologia 588 (1), $\underline{245}$ e $\underline{259}$.

Fang, T.H., Lin, C.L., 2002. Dissolved and particulate trace metals and their partitioning in a hypoxic estuary: the Tanshui estuary in northern Taiwan. Estuaries $25(4 \mathrm{~A}), 598 \mathrm{e} 607$

Fu, I., Tang, X.L., Zhang, J., Balzer, W., 2013. Estuarine modification of dissolved and particulate trace metals in major rivers of East-Hainan, China. Continent. Shelf Res. 57, 59 e 72.

Gaillardet, J., Viers, J., Dupré, B., 2014. Trace Element in river waters. In: Holland, H.D., Turekian, K.K. (Eds.), Treatise on Geochemistry, second ed., vol. 7. Oxford Elsevier, pp. 195e 235 .

Giri, C., Ochieng, E., Tieszen, L.L., Zhu, Z., Singh, A., Loveland, T., Masek, J., Duke, N. 2011. Status and distribution of mangrove forests of the world using earth observation satellite data. Global Ecol. Biogeogr. 20 (1), 154 e 159.

Greger, M., Kautsky, L., Sandberg, T., 1995. A tentative model of Cd uptake in Potamogeton pectinatus in relation to salinity. Environ. Exp. Bot. 35 (2), $\underline{215}$ e 225.

Gustafsson, I.P., Tin, N.T., 1994. Arsenic and selenium in some Vietnamese acid sulphate soils. Sci. Total Environ. 151 (2), $153 \mathrm{e} 158$.

Harbison, P., 1986. Mangrove muds da sink and a source for trace metals. Mar. Pollut. Bull. 17, 246 e 250 .

Hatje, V., Birch, G.F., Hill, D.M., 2001. Spatial and temporal variability of particulate trace metals in Port Jackson estuary, Australia. Estuar. Coast Shelf Sci. 53 (1), 63 e 77.

Hatje, V., Payne, T.E., Hill, D.M., McOrist, G., Birch, G.F., Szymczak, R., 2003. Kinetics of trace element uptake and release by particles in estuarine waters: effects of $\mathrm{pH}$, salinity, and particle loading. Environ. Int. 29 (5), 619 e 629.

Hien, P.D., Binh, N.T., Ngo, N.T., Ha, V.T., Truong, Y., An, N.H., 1997. Monitoring lead in suspended air particulate matter in Ho Chi Minh City. Atmos. Environ. 31 (7), $\underline{1073} \mathrm{e} \underline{1076}$

Hien, P.D., Binh, N.T., Truong, Y., Ngo, N.T., 1999. Temporal variations of source impacts at the receptor, as derived from air particulate monitoring data in $\mathrm{Ho}$ Chi Minh City, Vietnam. Atmos. Environ. 33 (19), $3133 \mathrm{e} 3142$.

Holloway, C.J., Santos, I.R. Tait, D.R. Sanders, C.J. Rose, A.L. Schnetger, B. Brumsack, H.-J., Macklin, P.A., Sippo, J.Z., Maher, D.T., 2016. Manganese and iron release from mangrove porewaters: a significant component of oceanic budgets? Mar. Chem. 184, 43 e 52.

Inoue, T., Asano, T., 2013. Characteristics of water quality and nitrogen-associated bacterial functions in Mekong delta mangroves. Global J. Environ. Res. 17, $\underline{199}$ e 206.

Jayasinghe, I., Phillips, M., Anas, M., 2010. Behaviour of environmental iron, manganese and aluminium in relation to brown/black gill syndrome in Penaeus monodon cultured in ponds on acid sulphate soils. Sri Lanka J. Aquat. Sci 13.

Kuenzer, C., Tuan, V.Q., 2013. Assessing the ecosystem services value of can Gio mangrove biosphere reserve: combining earth-observation- and householdsurvey-based analyses. Appl. Geogr. 45, 167e 184.

Kutscher, D., Wills, J.D., McSheehy, D.S., 2014. Analysis of High Matrix Samples Using Argon Gas Dilution with the Thermo Scientifc ICAP Q ICP-MS. Technical Note 43202. Thermo Fisher Scientific, Bremen, Germany.

Lacerda, L.D., Martinelli, L.A., Rezende, C.A., Mozetto, A.A., Ovalle, A.R.C., Victoria, R.I., Silva, C.A.R., Nogueira, F.B., 1988. The fate of heavy metals in suspended matter in a mangrove creek during a tidal cycle. Sci. Total Environ. 75, 249 e 259 .

Lee, S.Y., Primavera, J.H., Dahdouh-Guebas, F., McKee, K., Bosire, J.O., Cannicci, S., Diele, K., Fromard, F., Koedam, N., Marchand, C., Mendelssohn, I., Mukherjee, N. Record, S., 2014. Ecological role and services of tropical mangrove ecosystems: a reassessment. Global Ecol. Biogeogr. 23 (7), 726 e 743. 
Lenoble, V., Omanovic, D., Garnier, C., Mounier, S., Donlagic, N., Le Poupon, C., Pizeta, I., 2013. Distribution and chemical speciation of arsenic and heavy metals in highly contaminated waters used for health care purposes (Sre-

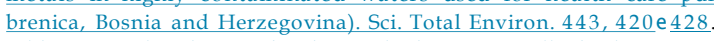

Leopold, A., Marchand, C., Deborde, J., Chaduteau, C., Allenbach, M., 2013. Influence of mangrove zonation on $\mathrm{CO} 2$ fluxes at the sedimenteair interface (New Caledonia). Geoderma 202 e203, 62 e 70 .

Liu, G., Cai, Y., 2010. Complexation of arsenite with dissolved organic matter: conditional distribution coefficients and apparent stability constants. Chemosphere 81 (7), 890 e 896.

Marchand, C., Fernandez, J.M., Moreton, B., 2016. Trace metal geochemistry in mangrove sediments and their transfer to mangrove plants (New Caledonia). Sci. Total Environ. 562, $216 \mathrm{e} 227$.

Marchand, C., Lallier-Verge s, E., Baltzer, F., Albe' ric, P., Cossa, D., Baillif, P., 2006. Heavy metals distribution in mangrove sediments along the mobile coastline of French Guiana. Mar. Chem. 98 (1), 1 e 17.

Masscheleyn, P.H., Pardue, J.H., Delaune, R.D., Patrick, W.H., 1992. Chromium redox chemistry in a lower Mississippi Valley bottom land hardwood wetland. Environ. Sci. Technol. 26 (6), 1217e 1226.

Minh, N.H., Minh, T.B., Iwata, H., Kajiwara, N., Kunisue, T., Takahashi, S., Viet, P.H., Tuyen, B.C., Tanabe, S., 2007. Persistent organic pollutants in sediments from Sai Gon-Dong Nai river basin, Vietnam: levels and temporal trends. Arch. Environ. Contam. Toxicol. 52 (4), 458 e $\underline{465}$.

Miola, B., Morais, J.O., Pinheiro Lde, S., 2016. Trace metal concentrations in tropical mangrove sediments, NE Brazil. Mar. Pollut. Bull. 102 (1), 206 e 209.

Nam, V.N., Sinh, L.V., Miyagi, M., Baba, S., Chan, H.T., 2014. Studies in Can Gio Mangrove Biosphere Reserve Ho Chi Minh City, Viet Nam. ISME Mangrove Ecosystems Technical Reports No. 6.

Natesan, U., Madan Kumar, M., Deepthi, K., 2014. Mangrove sediments a sink for heavy metals? An assessment of Muthupet mangroves of Tamil Nadu, southeast coast of India. Environ. Earth Sci. 72 (4), 1255e1270.

Nguyen, T.V.H., Takizawa, S., Oguma, K., Phuoc, N.V., 2011. Sources and leaching of manganese and iron in the Saigon River basin, Vietnam. Water Sci. Technol. 63 (10), $2231 \mathrm{e} 2237$

Nguyen, V.T., Ozaki, A., Nguyen Tho, H., Nguyen Duc, A., Tran Thi, Y., Kurosawa, K. 2016. Arsenic and heavy metal contamination in soils under different land use in an estuary in northern Vietnam. Int. J. Environ. Res. Publ. Health 13 (11).

Ni, H.G., Lu, F.H., Luo, X.L., Tian, H.Y., Zeng, E.Y., 2008. Riverine inputs of total organic carbon and suspended particulate matter from the Pearl River Delta to the coastal ocean off South China. Mar. Pollut. Bull. 56 (6), 1150 e1157.

Noe€lı., Marchand, C., Juillot, F., Ona-Nguema, G., Viollier, E., Marakovic, G., Olivi, L., Delbes, L., Gelebart, F., Morin, G., 2014. EXAFS analysis of iron cycling in mangrove sediments downstream a lateritized ultramafic watershed (Vavouto Bay, New Caledonia). Geochem. Cosmochim. Acta 136, 211 e 228.

Otero, X.L., Ferreira, T.O., Huerta-Díaz, M.A., Partiti, C.S.M., Souza, V., Vidal- Torrado, P., Macías, F., 2009. Geochemistry of iron and manganese in soils and sediments of a mangrove system, Island of Pai Matos (Cananeia d SP, Brazil). Geoderma 148 (3e 4 ), 318 e 335.

Oursel, B., Garnier, C., Pairaud, I., Omanovi' c, D., Durrieu, G., Syakti, A.D., Le Poupon, C., Thouvenin, B., Lucas, Y., 2014. Behaviour and fate of urban particles in coastal waters: settling rate, size distribution and metals contamination characterization. Estuar. Coast. Shelf Sci. 138, 14 e 26 .

Oxmann, J.F., Pham, Q.H., Schwendenmann, L., Stellman, J.M., Lara, R.J., 2010. Mangrove reforestation in Vietnam: the effect of sediment physicochemical properties on nutrient cycling. Plant Soil 326 (1 e 2), $225 \mathrm{e} 241$.

Phuong, N.M., Kang, Y., Sakurai, K., Iwasaki, K., Kien, C.N., Van Noi, N., Son, L.T., 2010 Arsenic contents and physicochemical properties of agricultural soils from the
Red River Delta, Vietnam. Soil Sci. Plant Nutr. 54 (6), 846 e 855.

Sanders, C.J., Santos, I.R., Maher, D.T., Sadat-Noori, M., Schnetger, B., Brumsack, H.-J. 2015. Dissolved iron exports from an estuary surrounded by coastal wetlands: can small estuaries be a significant source of Fe to the ocean? Mar. Chem. 176, 75 e 82 .

Santos, I.R., de Weys, J., Eyre, B.D., 2011. Groundwater or floodwater? Assessing the pathways of metal exports from a coastal acid sulfate soil catchment. Environ. Sci. Technol. 45 (22), 9641 e 9648.

Shynu, R., Rao, V.P., Sarma, V.V.S.S., Kessarkar, P.M., Murali, R.M., 2015. Sources and fate of organic matter in suspended and bottom sediments of the Mandovi and Zuariestuaries, western India. Curr. Sci. 108 (2), 226 e 238.

Strady, E., Dang, V.B., Nemery, J., Guedron, S., Dinh, Q.T., Denis, H., Nguyen, P.D. 2017a. Baseline seasonal investigation of nutrients and trace metals in surface waters and sediments along the Saigon River basin impacted by the megacity of Ho Chi Minh (Vietnam). Environ. Sci. Pollut. Res. Int. 24 (4), 3226 e 3243.

Strady, E., Tuc, D.Q., Ne' mery, J., Nho, N.T., Gue drone, S., Sang, N.N., Denis, H., Dan, N.P., 2017b. Spatial variation and risk assessment of trace metals in water and sediment of the Mekong Delta. Chemosphere 179,367e 378 .

Szymczycha, B., Kroeger, K.D., Pempkowiak, J., 2016. Significance of groundwater discharge along the coast of Poland as a source of dissolved metals to the southern Baltic Sea. Mar. Pollut. Bull. 109 (1), $151 \mathrm{e} 162$.

Tuan, V.Q., Kuenzer, C., 2012. Can Gio Mangrove Biosphere Reserve Evaluation 2012: Current Status, Dynamics and Ecosystem Services. IUCN, Ha Noi, Viet Nam, p. 102.

Turner, A., Millward, G., Bale, A., Morris, A., 1993. Application of the KD concept to the study of trace metal removal and desorption during estuarine mixing Estuar. Coast. Shelf Sci. 36 (1), 1e13.

USEPA, 2007. Method 3051A: Microwave Assisted Acid Digestion of Sediments Sludges, Soils, and Oils, Part of Test Methods for Evaluating Solid Waste. Physical/Chemical Methods. US Environmental Protection Agency.

Viers, J., Dupre, B., Gaillardet, I., 2009. Chemical composition of suspended sedi ments in World Rivers: new insights from a new database. Sci. Total Environ.

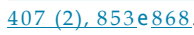

Vo, P.L., 2007. Urbanization and water management in Ho Chi Minh city, Vietnamissues, challenges and perspectives. Geojournal 70 (1), $75 \mathrm{e} 89$.

Wang, Y., Liu, R.H., Zhang, Y.Q., Cui, X.Q., Tang, A.K., Zhang, L.J., 2016. Transport of heavy metals in the Huanghe River estuary, China. Environ. Earth Sci. 75, 288

Wang, Z.-L., Liu, C.-Q., 2003. Distribution and partition behavior of heavy metals between dissolved and acid-soluble fractions along a salinity gradient in the Changjiang Estuary, eastern China. Chem. Geol. 202 (3 e 4 ), 383 e 396.

Wen, Y., Yang, Z., Xia, X., 2013. Dissolved and particulate zinc and nickel in the Yangtze River (China): distribution, sources and fluxes. Appl. Geochem. 31, $\underline{199}$ e 208.

Yanan, Z., Li, H., Kai, Y., Yiqun, G., 2017. The role of dissolved organic matter in the competitive adsorption to Goethite, during arsenic mobilization. Proc. Earth Planet. Sci. 17, 424 e 427

Yang, X., Wang, Z.L., 2017. Distribution of dissolved, suspended, and sedimentary heavy metals along a salinized river Continuum. J. Coast Res. 33 (5), $1189 \mathrm{e} 1195$. Yang, Z.F., Xia, X.Q., Wang, Y.P., Ji, J.F., Wang, D.C., Hou, Q.Y., Yu, T., 2014. Dissolved and particulate partitioning of trace elements and their spatial-temporal distribution in the Changjiang River. J. Geochem. Explor. 145, 114 e 123.

Yao, Q.Z., Wang, X.J., Jian, H.M., Chen, H.T., Yu, Z.G., 2016. Behavior of suspended particles in the Changjiang Estuary: size distribution and trace metal contamination. Mar. Pollut. Bull. 103 (1 e 2), 159 e 167.

Zhang, D., Zhang, X., Tian, L., Ye, F., Huang, X., Zeng, Y., Fan, M., 2013. Seasonal and spatial dynamics of trace elements in water and sediment from Pearl Rive Estuary, South China. Environ. Earth Sci. 68 (4), 1053 e 1063. 